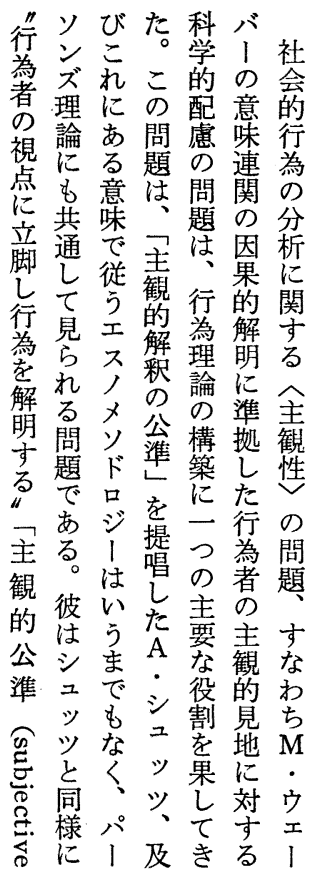

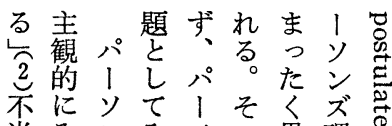
当みンみンこ異理敋

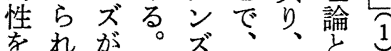
論た主壵エそ至を ず行意如スのス遵

る為主何ノ差ノ守

$こ の$ 義

とすの

にべ構

あて築

っをを

た実企

証 て

な科た

わのは取ををこ成

ち方、り明決のに

行論認扱確定問着

為的識たすけにし

を図な的のるてつた

”式局少たいい

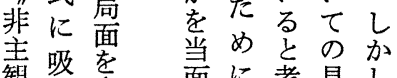

観吸含面に考䟺し

条すめ課ま苂がパ

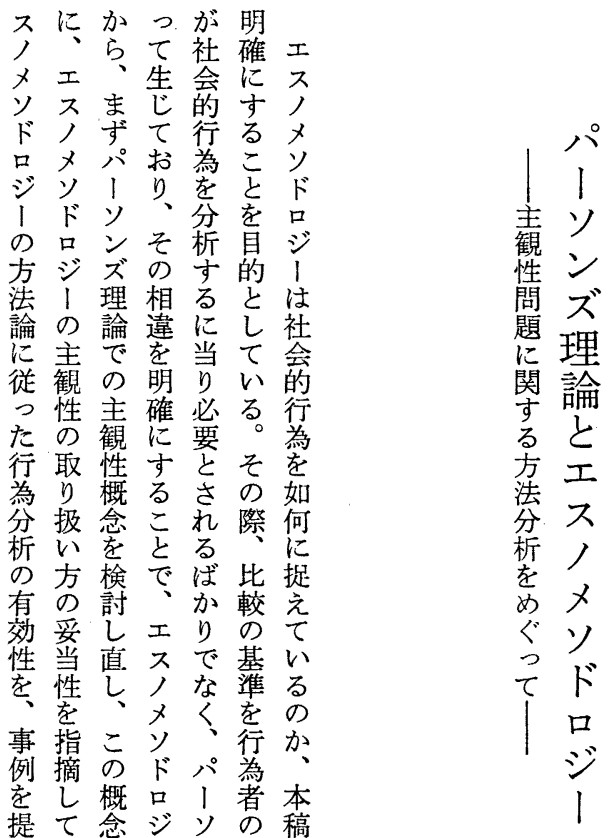

示、立、ン主で

し最行のズ観は

な゙後為理理性こ ら、状ととも課 論工況そ工 $匚$ 題 じとのスくを て,ノの存ノは従 文 メ関在 メ主来 るソ係価ソ観の ドを值 ゙的社 口エを口意会 ジス問 ジ味学 をくうとと閏 特 具ソとの題に 体ドが差にパ 的口で㤎求 I 北 にジき本めソ 紹】る㬅る。 介の加的。理 す視らにこ点では浬 意とあこ問と 味対るの題の 女照。問注比裕 含守こ題、較 める。の艺社に 工次点ぐ学り 
ユと実し害内徳をな゙とかの面シにに $\mathrm{E}$ 总ンこさ件

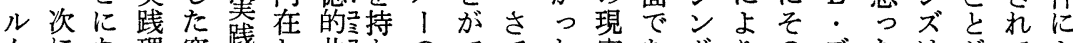
ケにな理究践し共棓らのでてた実あボりのデたはがてよ 厶、る性極性て同变、カき、とのるル解指二要、、、いり は究。的的“性い体そりる主考分のの決示ル素実主る説 道極な価とるをれス $九$ 観え析に指し内的証意行明 徳的值呼わ形が、合的てを、示よ容么焦主主為方 的価道あびけ成集を只カい放科内 うにと点義義者る

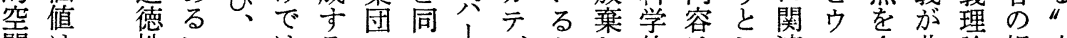

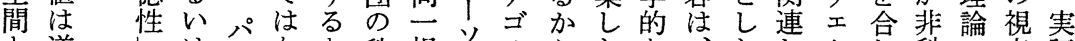

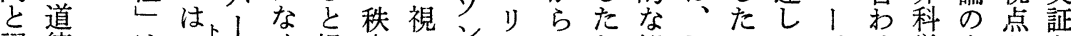
認德は超ソく捉序しでリでた観々のてバせ学出か主 知性主超ン、えにあ察間でい! る 的発ら義

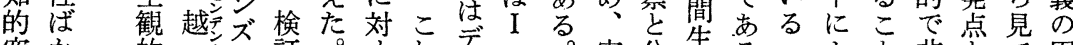

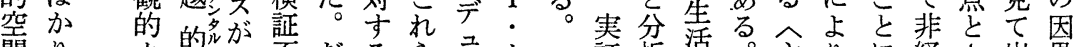
間りカ的が不だるらユカ証析活す主りに経さ出果 とで デ規個哥が正はルケ、主の体な観、指な験れ現律 をなゴ範产人能、当共公卜義範体ぜ的摘る的たしに

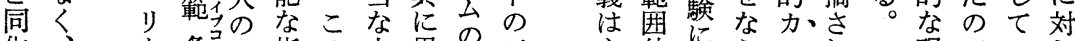
化: I条志心指の力畏の三

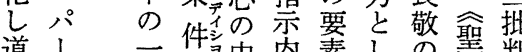
道 1 - 件音中内素しの䘫判 德ソ 部でに容経機態な従 にズしるるみつ験能莫る徒 認にて。存まさ喻モ再 知よ扱を在り炛る起分

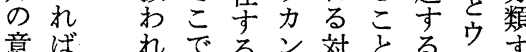

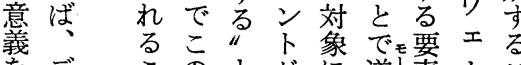

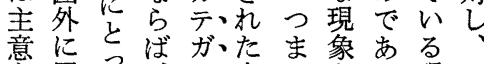

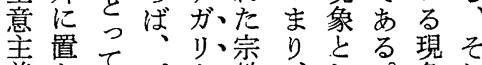
義古意パ!教、し。象れ 的れ意 IVシ彼てこ”孝 性た義ソの、ンは無のと” 格岕るン析ボこ視場し分 を 取と実特明、公問究パ解さ 得、の定確、題明 1 寸考 なこ局の化特ををソる察

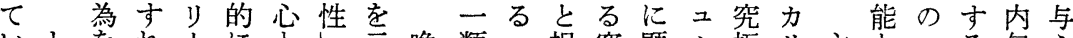
いしをれさにと示晚類”捉究顕ル極り主とつる包え るか把价、主しに唆年型審え極著ケ的ス観な悟認して わむ握、を観たかし、美る的に公価、的る性知てお け一乙基的行かて再み的。価現の值と感劣的基いり

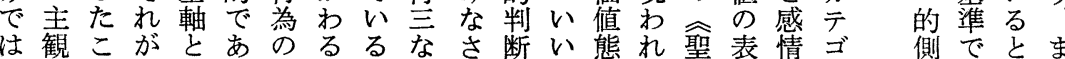
な的と、しる準非とされ力か度的出的り面あさた くカをすだ扰検考れる゙えで儀なに信、をるれテ意な理と枠証えた。にれあ礼るよ念の第限る方

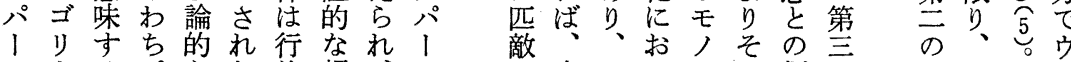
ソ】るパなた為超、ソ究こけのの類の 主そし ンに。1集の者越究ン、極のる崇補悠内 ズ依り拠での的極 ズこ的現熱拝完性容

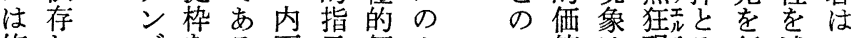
修し ズをる面示価カ 正たに用。的内值ン を方意し事容は穴 加法っした柄で局閤 なは行こつ属る徳す が主為れて方が性る ら意者に、、ゆし言 も主少よ全とえ屋及 そ義視り主りに悟潅り れ点行観わ性以 を限立為的汇こし立 継さ立分テ内热感内 承れ行析 $コ$ 在中情容

感值社現そ行述感 情 感会は天実と、情 性情 の社践考感性 的連会的光情 は表带に表てはで 主象性共出心力あ 観はを通でるリる 的力強のあ。ス カン化価るこマパ テトす值儀のが ゴのるを礼内内ソ リ指原表の容示ン ।摘理出概はす のすだす念デるは
主そし 的はたバ 力力か । テン?の ゴトてカ リの 究 リ 之純極㕛 し 粋的爷 七理 価超 類 性 值 自 別 “架然 すに界性 る相界潅 こ当觀 世 㤂、関 観 可こ与を 
るズでかた認素ばし数る数関で認的はが捉力あし、

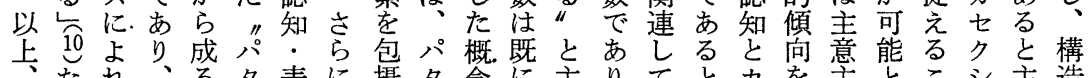

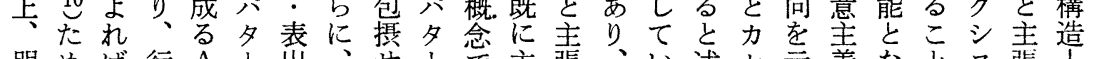

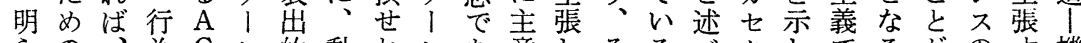
らの、為 $G$ ン的動ねンあ意しそる心゙クしでるがのす機 か理 $\mathrm{A}$ 者 I 変シ機 ば変り兲ての評るシて示。で動る能 に論 $G$ の $L$ 数ン志な数、義い選価と不いさつき機 6 分 パ図 I 視図のボ向らのこでる択的同的るれま志机析

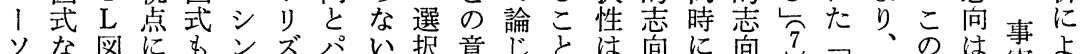

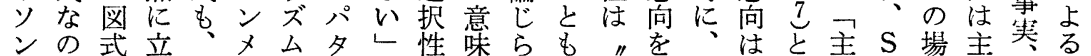
ズでは脚当トに、 8 方でれ周行重本ウは観・合観構社

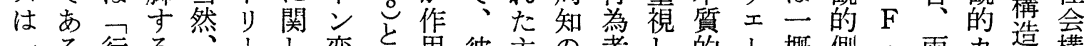

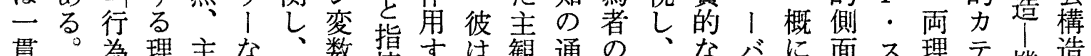
貫。為理主な、数摘すは観通の、なバに面ス理テ機造

し 者論観対評が風る、的り主こ方ははコ論ゴ能の

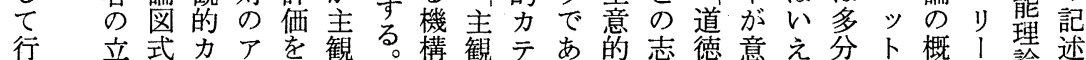

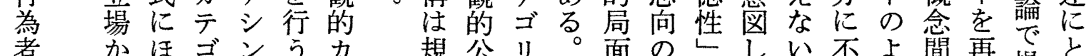
者かほゴンう力

のらかリメ意テ

人、社な।ト味 ゴ

主会らを精号でリ

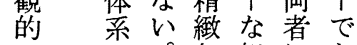

カを。化組にあ

テ概ハし合配る

ゴ 概、たせ分以

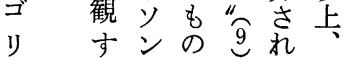

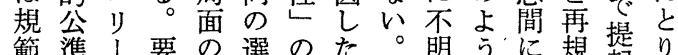

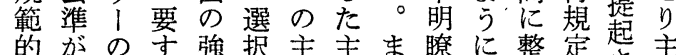
に的がの省強贽主主ま瞭に整定起主 意角道に学容的的た觀た造性たれ隹 義さ徳、明がカ視パれ!省概た評視 あれ性パ晰パテ点! 、機与念価点 るるレタ化タゴそソ行能えで価は 構るを、化、リのン動主るあ認重

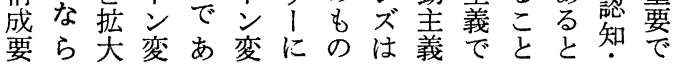

析のリの本にり てな普行の に在はず関節分説主お明観り。遍為般主 対論々上䓃は可さ的、乙妥況的観 抗的要述行分能れ力そか当に普性

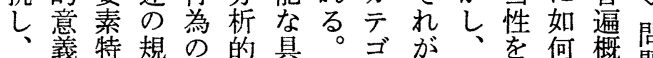
行、性定一リ体そリへ両標な念題 為す㤎般了的れ门主者傍ると関 のなとら的り現はの観㤎意し等 構わし、普ズ象、意性措る義てする 造ちて行遍么の科義定限を使

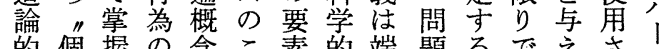
的個握の念こ素的端題るでえさり 意々さ一ののに概的に行はてれて 義のれ般問要対念に影為エいで゙ と社た的題素応は周響のスるい理 し会も普をとす、知老一ノのる論 て的の遍考対る具の㞧般メ加主論

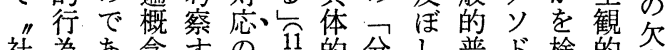
社為あ念玄の 11 的分し普ド検的点 会とりとる視と現析て遍口討力点 的は、さ点し象的い概 济し テ論 行何ウれ以にたでリる念!で゙論 為加る下拉はア。方文みリる

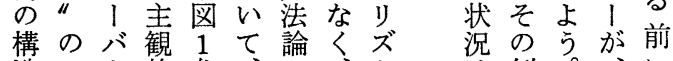

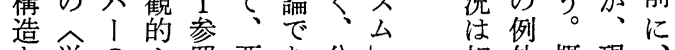
と単のカ照要あ分し相外概現 は位行テ英る析に 反で念実行 何分為ゴと。的よし念の為

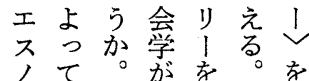
ノでな提準し考 ソはぜ起拠か慮 ド必なし準し、に 口ずらたの、入 ジしばへ骨これ 1。、主子のる の充全観と理こ 文足主性乞論と 脈さ惟性七的で にれ性問行に

見な 問題為一行 いい閴をを般為 出之題解分的者 さす注明析普の れる パす守遍視 る反合るる性点 加駁、唯方学妿 らが光法与ら で、瓷適論え行 あシ的正は方為

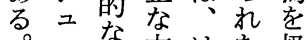
ツな方はた扱 ツ理法た主っ に論なし観て 論方のて的き 拠方で理力た し法あ解テと たにろ社ゴい 
図 1 パーソンズ理論とエスノメソドロジーの概念対照

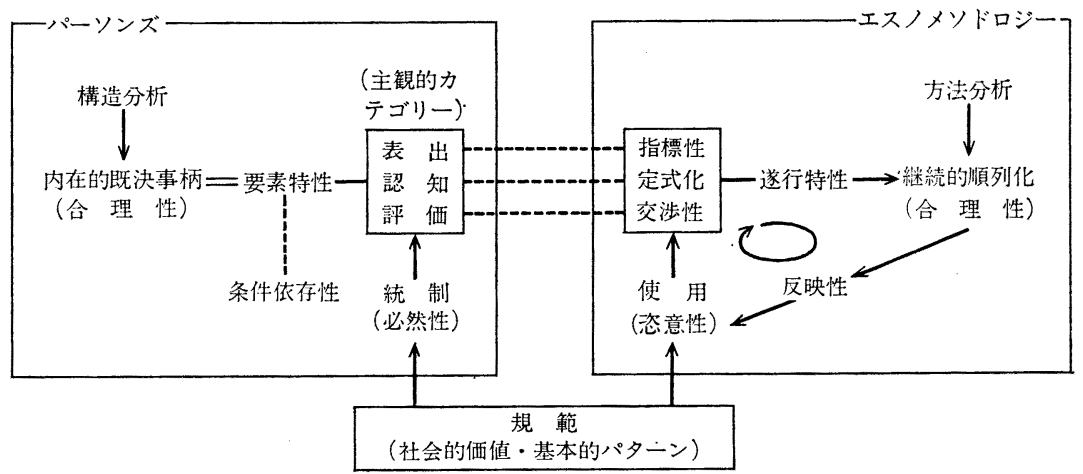

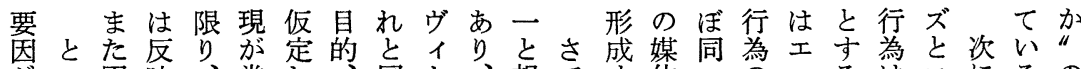
分置映、常し

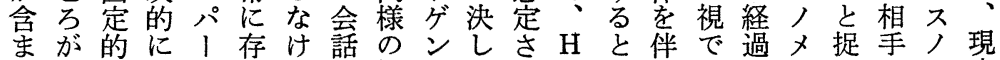
れ、ななソ在れ妿概シてれ、みいきやソえのメ実 てパ内さン尔ば状念ュ同たガな、る状ドた出ソの

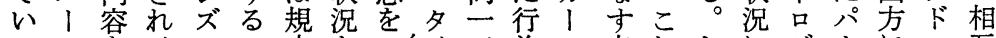

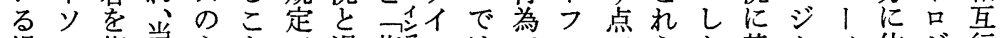

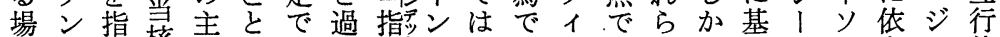

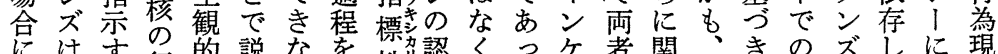

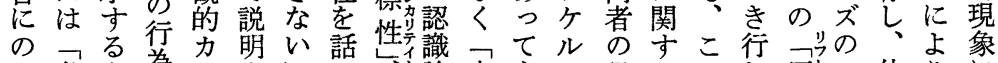

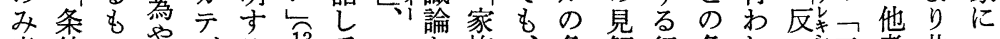

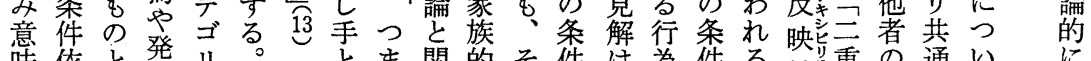

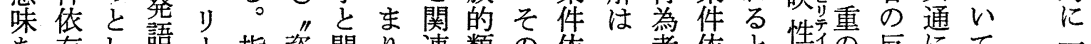

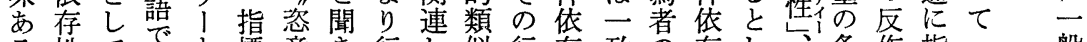
る性てでと標意き行し似行存致帛存し十条作指二般

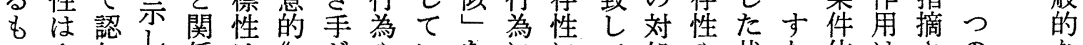

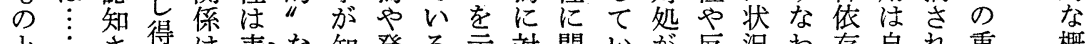

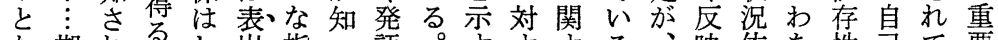

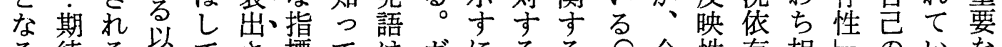
る街る以てさ㮏て注ガにるるす12合性存相圠のいな

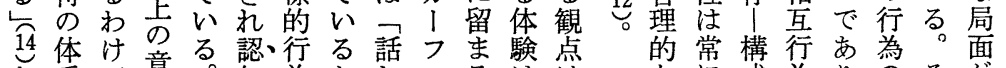
と采で意。知為加し1る哭注

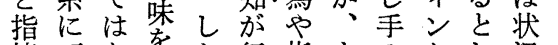

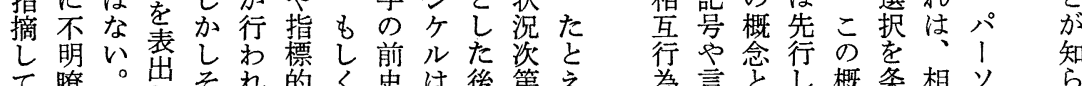

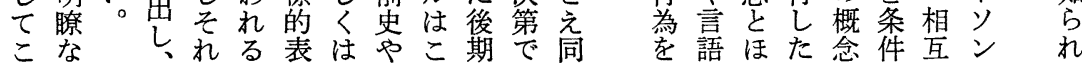
$35(1 \cdot 61) 61$ 社会学評論 
的的規る同行閒内結もけこ行に行の決のかや避の “ま普範こ。一為にの合の相の為合為前定合らシ涹不

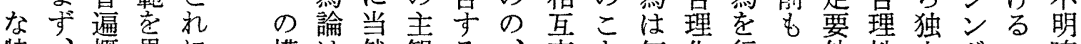
特、概異に構は然観る、交と何化行っ件性立ボこ瞭

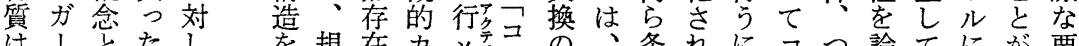

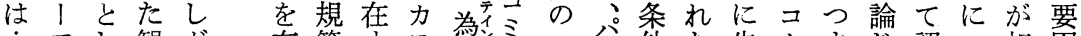
$\vdots$ フし観ガ 有範守テ為ミ一ハ件た先 lまじ認一相因

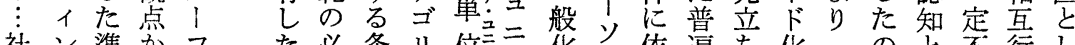

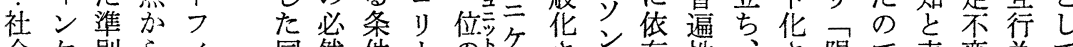

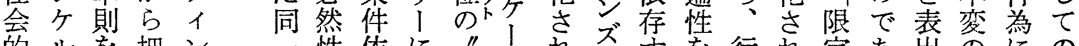

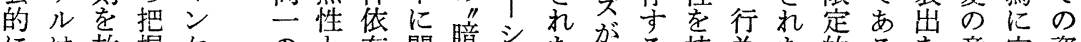
には放握ケのと存関箱ヨた相る持為た的るを意安恣

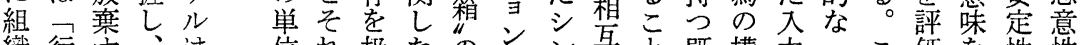

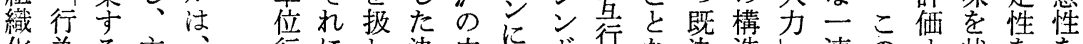

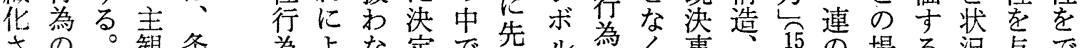

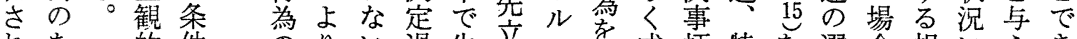

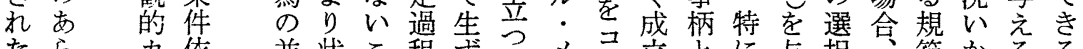
たら力依並状こ程ずつメ主とに立択範かるる

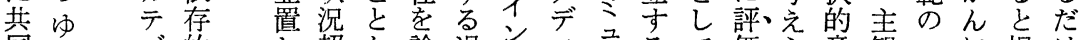
同る ヨ゙的し超か論過プイニるて価ら意観”に捉け

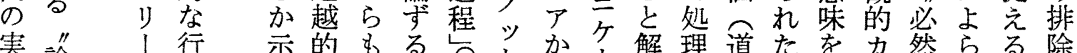

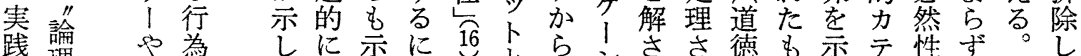

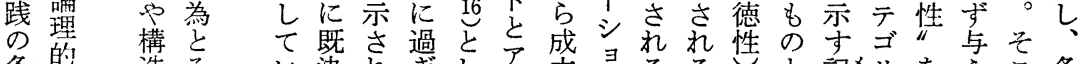

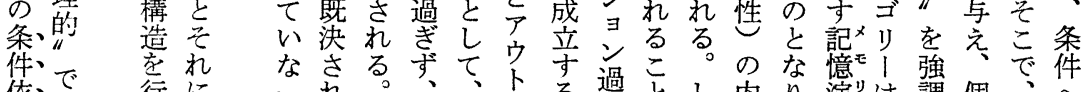

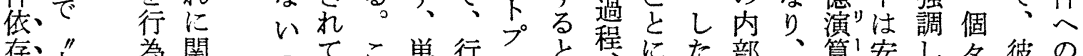

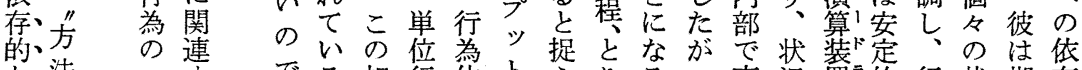
な法一寻でる相行体卜元りるっ事況叠う的行状期存 遂論般る あ互為系をるわ。て前は上な為況待を

涉れ化カフ価ド的と行さばも在にな一寒照のと行 だ“、にテイにロ次順し行れれ顕的付遂般践的内主 がに条対ゴンよジに列て為たた在に帯行的的に容張。

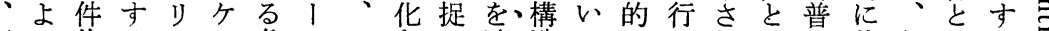

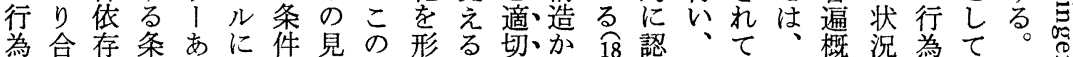

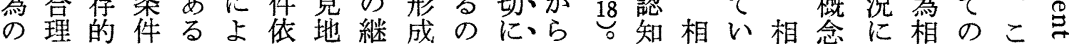
合化な依いれ存に続せで遂成い可互る互を従互主れ。 理が相存は柱性立的ねあ行るい能行指行措っの観は 性行互的一、のっ順ばるす、諸かな為標為定て条的 をわ行な般合回た列な。る行年解の性の卞遂件力パ完

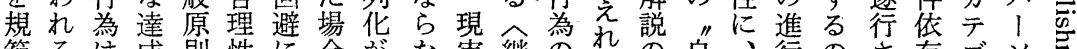

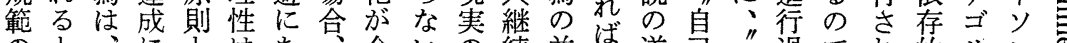

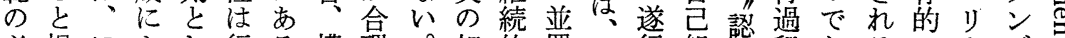
必捉ほよし行る構理。相的置相行組知程あるで! ズ 然えかって為の造的互順で相は織可のる゙継をがと 性らなてよ者でにに, 行列は豆定化能中。と続二行し とれらのり㤎はか秩為化な為定“なでこい的般為て

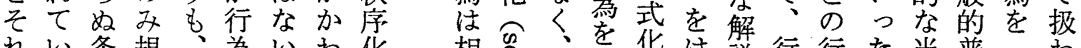

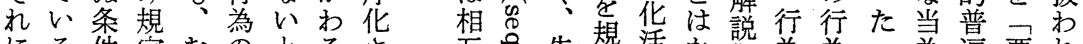
にる件定むのとるさ互芑先䉒活か説為為為遍要れ

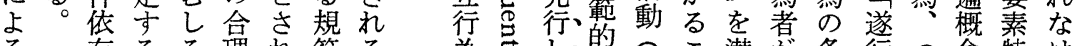

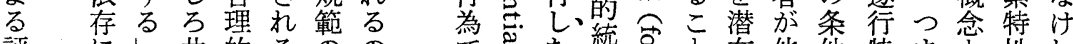

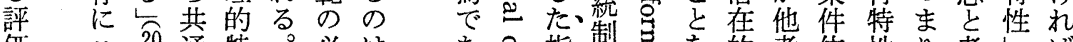

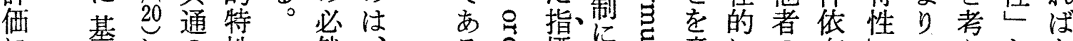

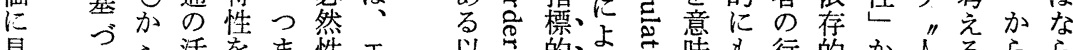

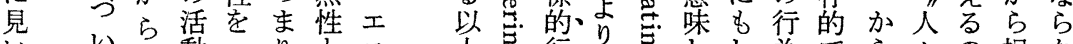

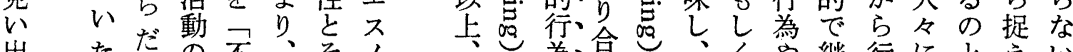

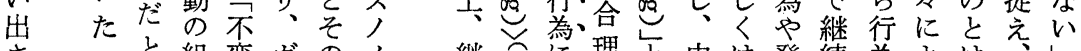

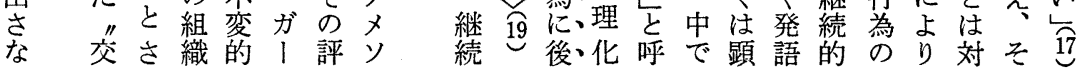


るす同涉焉状るを実が的映対示すミるい等式るい

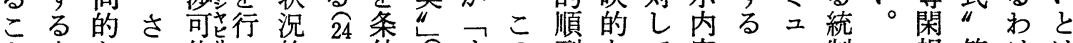
方なて能以的妿件 $\overparen{23}$ す列なて容こ二制エ視等けは が法企、性、、に要依意化指で“とテにスしのでい

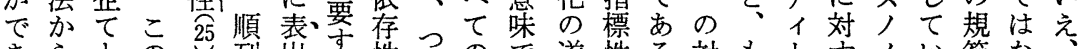

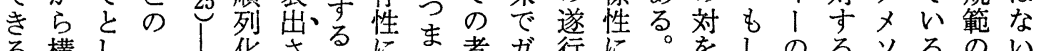
る構し、华さるに皇ガ行に者ししのるソるのいエ 形成て遂がを机従自が、架関も二く成過ドと存。ス

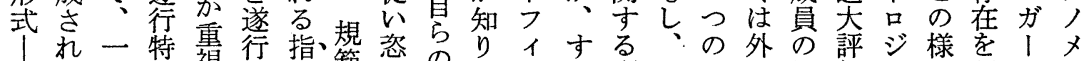

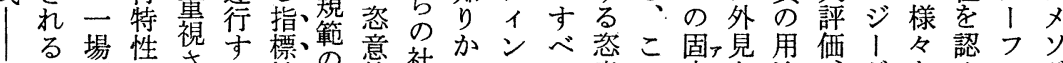

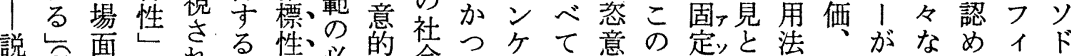

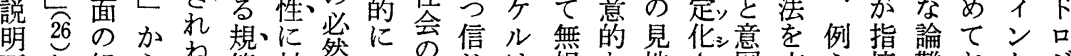

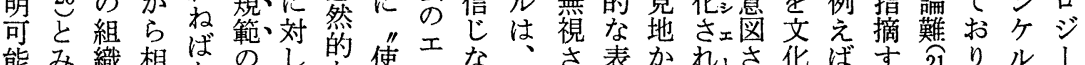

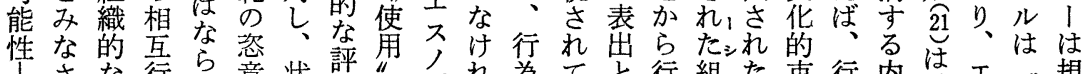

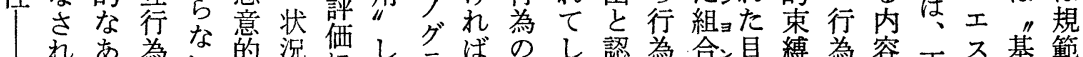
で市為な的洗にしうばのし認為合䀯為容正基範

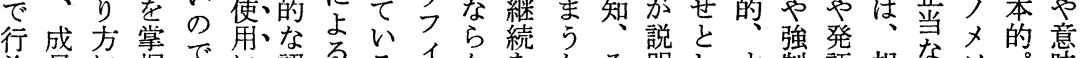

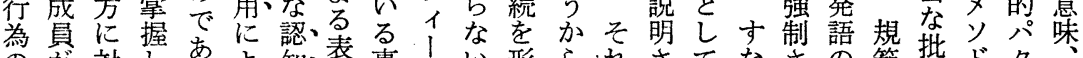
のが対しあよ知表事、、い形られさてなさの範批ド夕 継互したる。ると、出実常化成にに杂解われ説の判口! 文

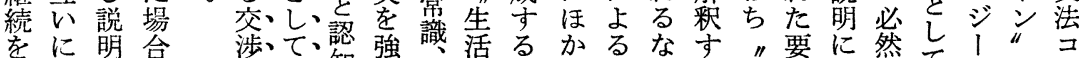
規納可只梁て知調信のたな交らる記請関性てがと、

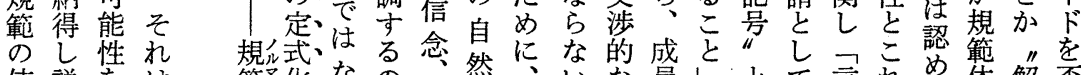

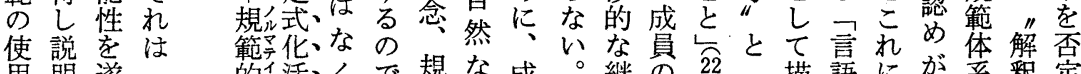

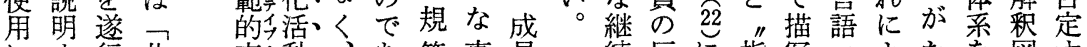

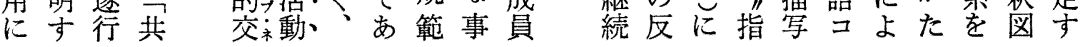

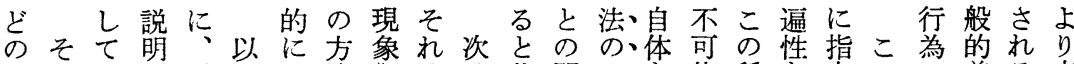
よれい可説上の法“帆共間一を能種を向のの普る交 うでる能明穴み㳊え説にに般二性の提す点順遍こ涉 なはのな可エ二、説琞、は化般に批示るに列概と的 意、゙も能 $ᄌ$ 般成で明可状何に华言判でエ関念念にに 義こあの性 $ノ$ 的員あ可能況ら関し及はきスしのとな遂

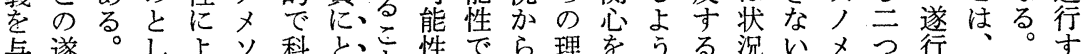

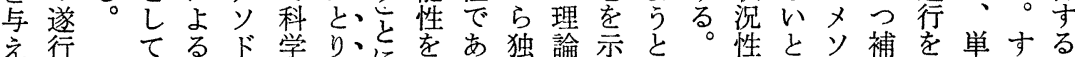

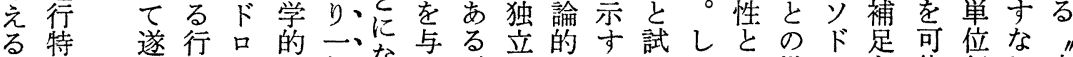
の性行為湆概般なえがし不のみかそ批口を能行わ方 かにさの!念的るるる、た整でてしの判涪しと為ち法

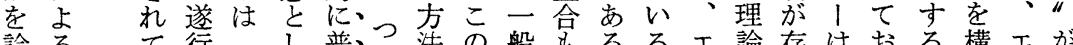
論るて行企普ま法の般もるるエ諭存は㧤る構エが

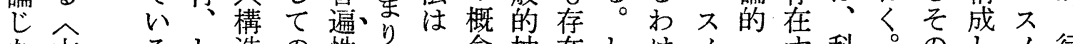
な方るし造の性、、“念抽在しけ人一守科。のし, 行 け法のた分み老行科は象したでメ般る学第”てメ為 机分 かが析普持為学成性ながはソ化が的一方いソの ば析“つ遍ち為者員索いつなドやて概に法るドな のてや的、—でに持。てく品状念、“構口般

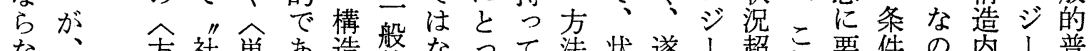
な、方社単あ造般なって法状遂 1 超こ要件の内内 普 い主法会位る内普くていは況行は越杜求依で容の遍

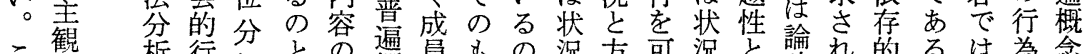
こ性 梠行析との遍員もの況方可況之論れ的るは為念

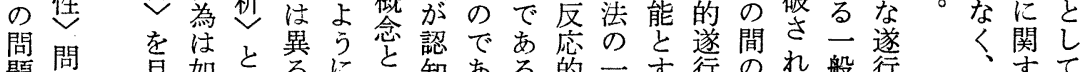

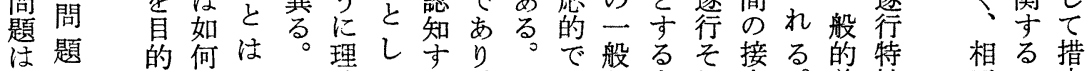

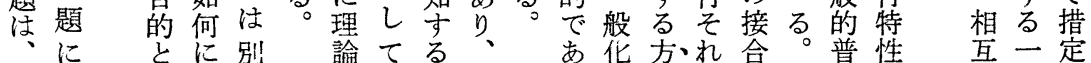




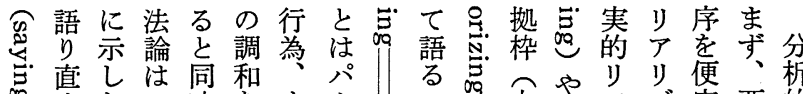

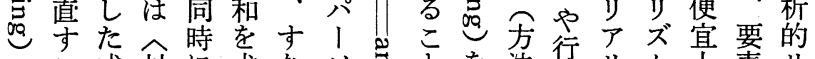
をこ成效求なり总と法為台上素り

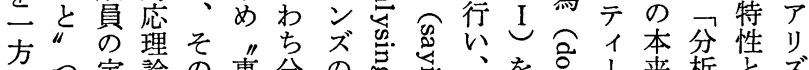
のつ定論の事分の品、を高、来析とズ

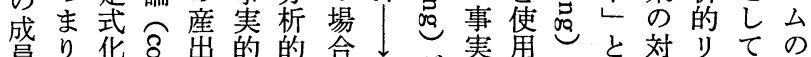

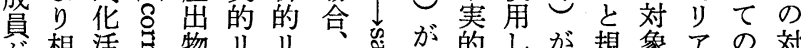

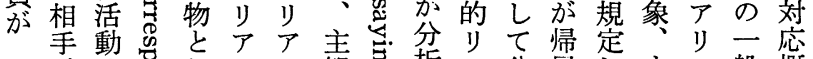
自吕は

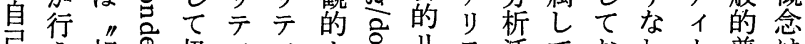

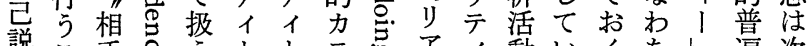

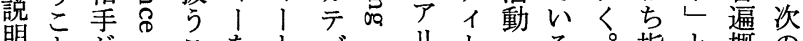

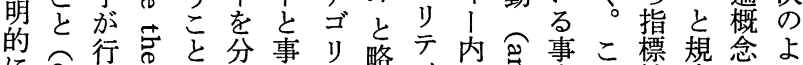

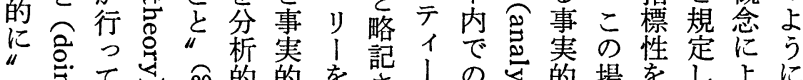

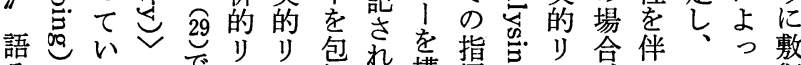

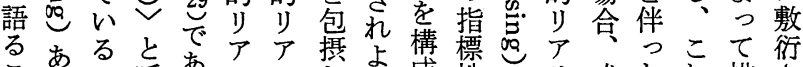
こるこ呼变りリしよ成性りり成たれ描さ

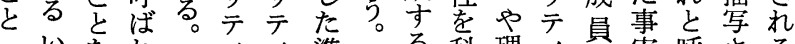

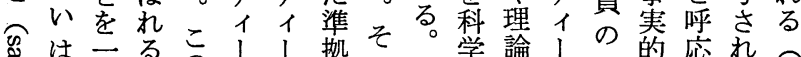

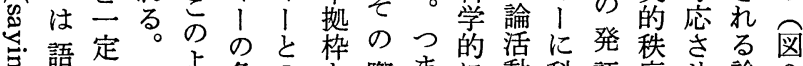
語定一よ条の榀際ま的㗢科語序せ論

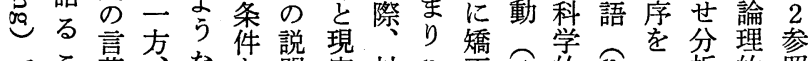
でこ葉なと明実対包正き的危析的照

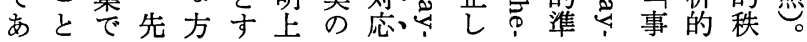

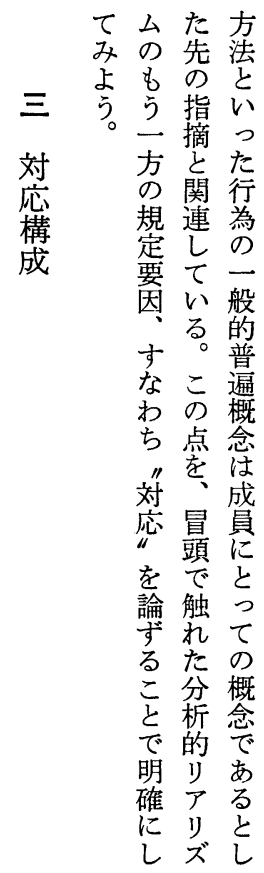

図 2

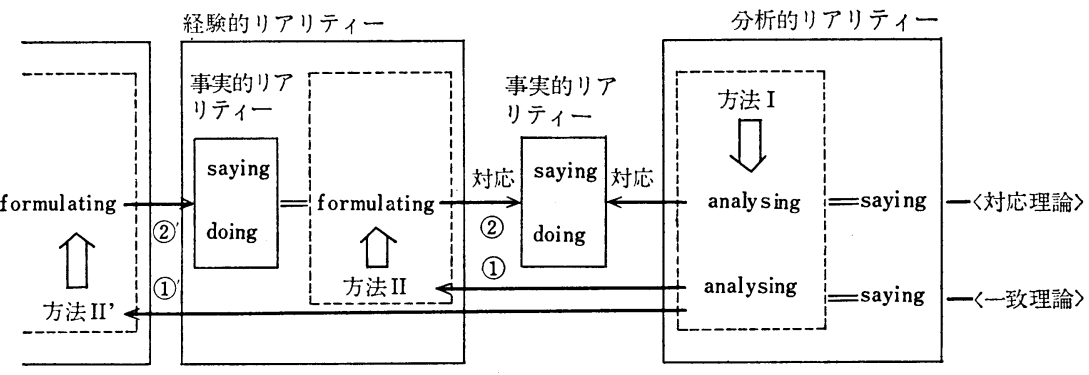




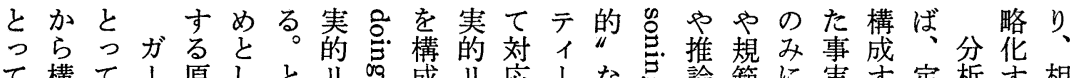

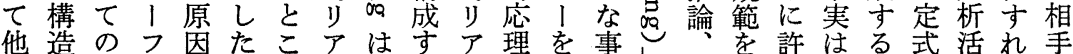
我化他イと従ろリ反るリ論際柄をす方さ、と化動ばの とさ我ンな来がテ映こテを限と卡な法机行考活が発 のれはケっのこイ れと的とイ構なし下わ的た為え動科学語

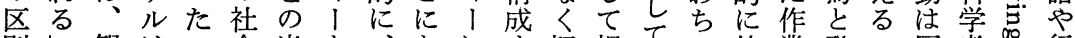

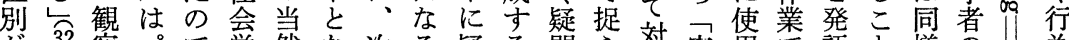

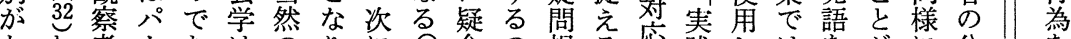
なと者はあはのり、な3念の視る構践しはをがに分灾を さみのソる看現、構导をしの構的っな説で、析哥維

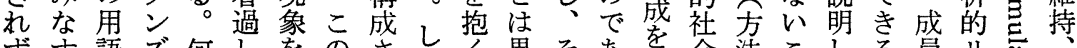

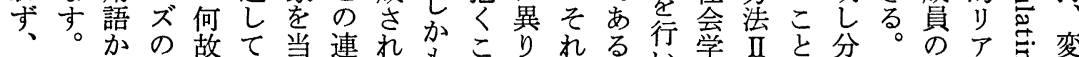

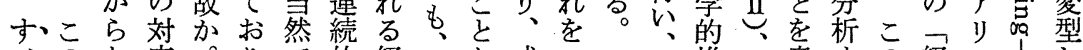

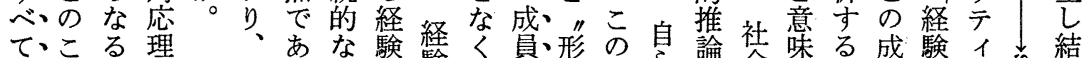
同々行論そる過的験対は式場

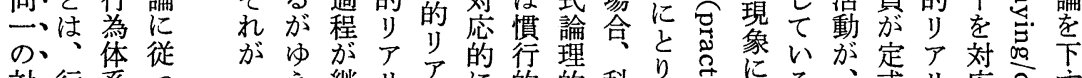

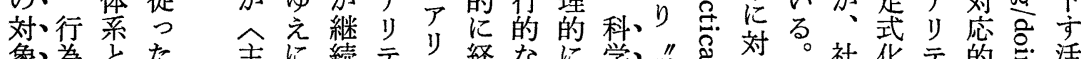
象為とた主に続テテ経なに学説き対。社化テ的导活 行者し場観。的1テ験規畣者説品昌成会活1に品動

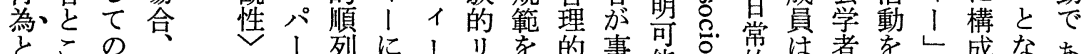

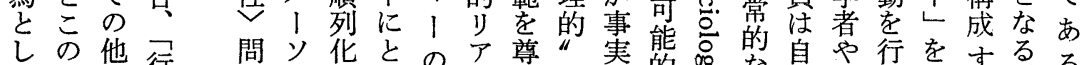

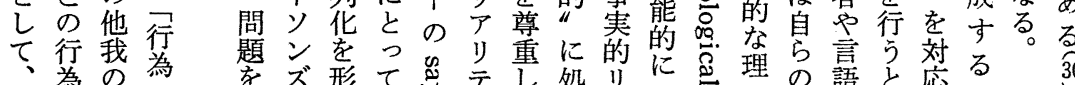

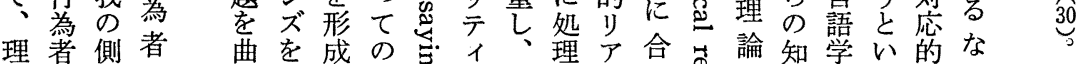

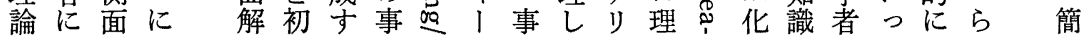

しよ方さ員的社 成仕れでさす素ではべ観 I上す的 も彼る法れがリ会蕆方るあれれ゙特も年る以的の述るな ちの関 II てそア学貝で事るるき性、日よ上カ区の。要 ろ手係をしのリのさ解実。しでに是常うのテ別リつ素

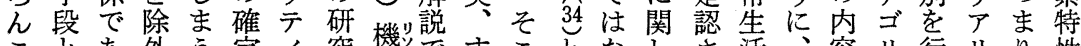
こ市外う定イ究機紧すことなしさ活、容り行りり、性 のしりしいを| 対略きなで述くてれの規にはわテ、に

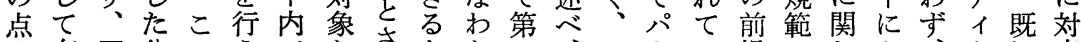
は有科分のうでかさとち方、一、い提のしよ、1に応 效学析よ定のられに科連ソるに必てり両区触さ 成で学的う式指排 $\widehat{35} つ$ 定、学のン現そ然指機リ分れせ 員あ孝りな华標除式た式継的綿ズ象っ性摘械アでたる のる観ア経活性さ経事化続な密はでたにさ的りのパこ 方に觀リ験動がれ経実を的論な子も事従れにテ事 ! 法過祭テ的に科る験は行順理過単な象 うるかイ奏ソで II ぎ能 1 リ関学こ的、え列性程にいの主事つ1 的ン等、

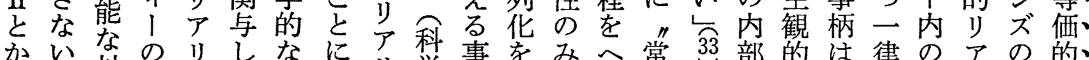
かいなのリしなに等事をみ常 33 部的は律のアの的、

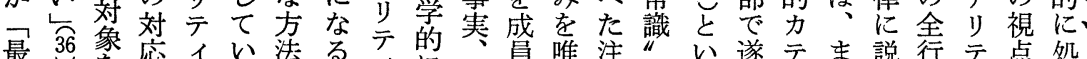
もの相構 1 るI I

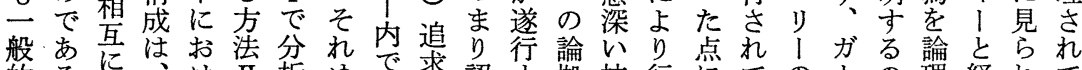

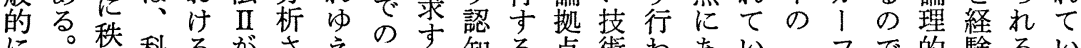
に。序科るがさ学定る知る点術わあいつフで的験るい

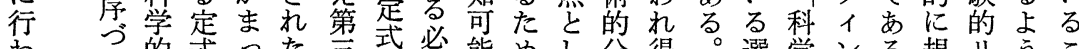
わ计式った言帒要能めし分得。選学ンる規りうこ れな华た場に活要なにて析る事択的ケ。定アに

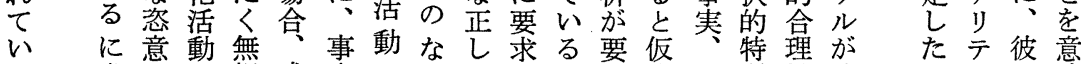
る際意視成実はいいささ求定要質性述主1 
テはいつ用、ソあ主連をない合アあえ対の得成は思

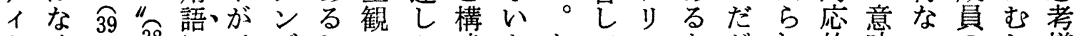
$1 く \underbrace{38}_{0}$ に示ズわの戊となてテとがれ的味いのし様 を、端とよ唆がけ実行しかぜいイ捉、る演吕分思ろ式 形成端の つしそで翼為てのなよ! 科加繹ら析考々は 成員に指でたのは的者い理らうを学もはすと様れ しがに針方体な内穴る論ば機そ的知袋概式に社 行事いに向現来い容視の的第械れ視れ主ば念で反会 為実忘論う実のとの点はな第、的ら点な観、構は生現 を的は拠けの意思科にこむ会にをのい性主成なる象

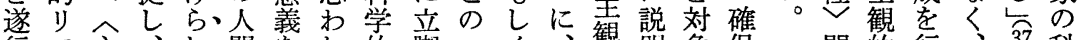
行了主、机間を机的脚一<、淮明象保問的行、 37 科 寸り観こ、の掌る精し般は一性すかに題力う科亡学 るテ性のそ行握か查て的倫般閏るらと合 と学指的 のィレ事れ為でらと行な理的䦗理排り、のゴす者摘研 か、問奏ははきでそ為思的な題論除 、題空彼旦なあれ学な思関は亭盛 ま対は究の常かる。分様価考関如事員 は如観す為思た全るすで判式適何的方 "何のるに考事主效るあ断が適にリ法 行に構こ支で满性怎“るに好正主了队 為自造亡配用、性的々こ先まな観り二 者方内で配いす問演は立し視的テ般

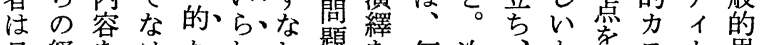
日経をけないれわ題を何次、を構テ、思

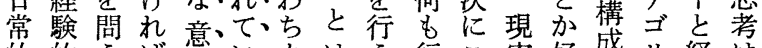
的的うば意、い、はう行こ実好成り経は

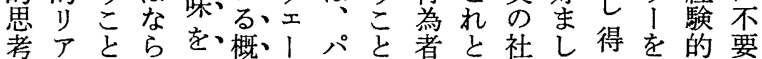
やリでな持念、゙、にの関会くな包りで

アリるのし究

プ、主理たに 口の張論 デと 1 理に的 二 つ チ論よ思ルて を的り考ケ好 行な正に允ま つ析当従をし た出化い初い 理とは、めも 論そさ素との でれれ人しで あをよで、あ る用う。は科る とい。成学よ 考たこしはり

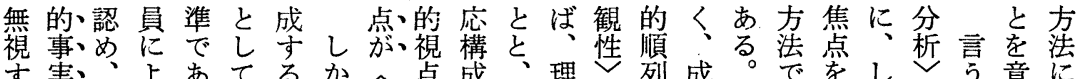

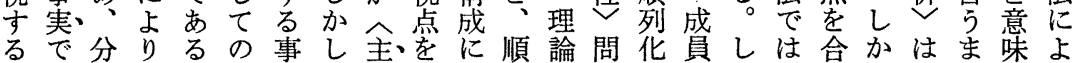
こし析方崖指実そ観保つ列的題をにたなおす、でしり

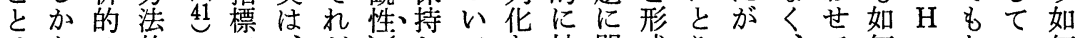
はなリ的こで、だレしてを抽関成りっ、て何・ない何 主いアにとあ科け問ての形出势卞有て成いにサくるに 観こリ捉にり学で題い分成しるる益員る認 的とテえな、者はを、る析すた正方な事の。知クエで為 視をイらる観にな解ととる主当法配実方こ可ススあを 点意】れ。察とい決はは成観なを列的法の能がノる。遂 に味にたこさっ。すい完員的方問でリと方な論メ。行

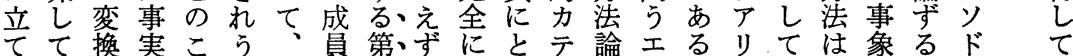
ないさ的とる成㤎一、別っゴたス経テ彼科とよ占い いるれリはす員方歩成のてリをノ験 ば。たア、のそ法な員も一－１考メ的１の的てに１

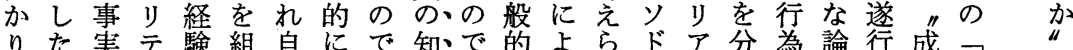

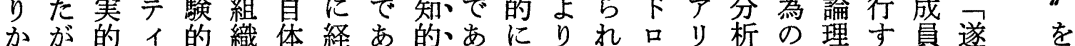
、っリ、化が験るなりり普対るジテ的遂領るが行、科

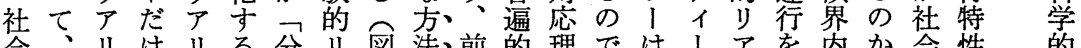

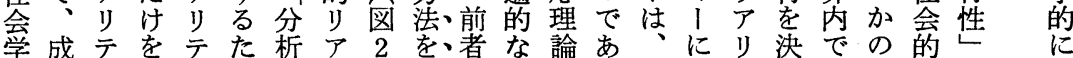
は員イ社、め的リ (1)問の方をる必編テ定妥方行に，明

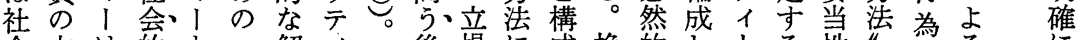

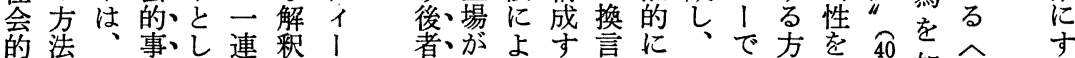

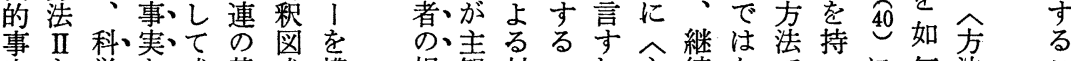
実を学、成基式構視観対これ主続なでつに·何法こ 
いるてりいに明い合もの、対法意に行よるな体法過で

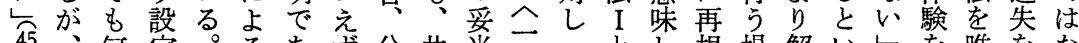

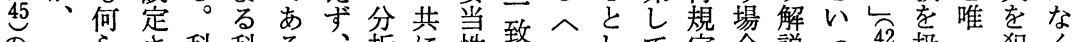
の゙般否れ学学とし活事性理致てい定合説っ あ的定る者理の加動実次論理”る りなさ限の論基もに的のは論二。そ行る寒えめ学と学

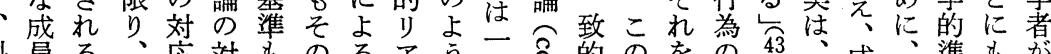

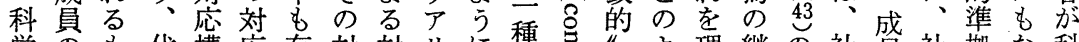
学のも代構応存対対りに種品“よ理継の社員社拠な科 的解の替成的在応応テ説の゚ミにう論続だ会唯会点る学

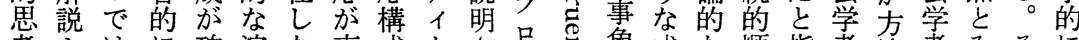
考よはに確演な事成ささ号象成な順指者法者みそに のりな成実繹い実がにれ卜るの員説列摘が严自なれ規 過利い筫な性。的特関るコ吉説の明化守人にらしゆ定

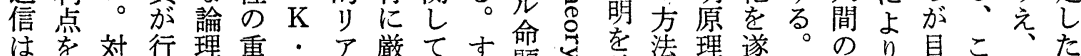
デ持応 $う$ 的視 $\mathrm{R}$ リ密対な題

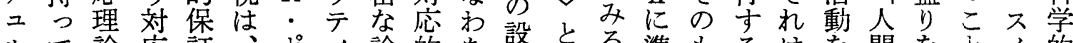

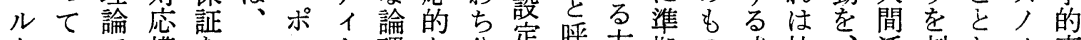
ケいで構をこッ1理な分定摇方拠の成社、活刻かメ事 厶るの成持のパに性説析類れ法し々員会こ動んらと実

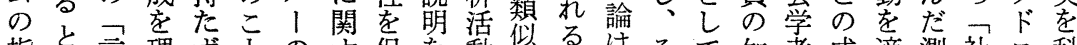
指と言理すをと守保老動似るはそて知者成適測社口科

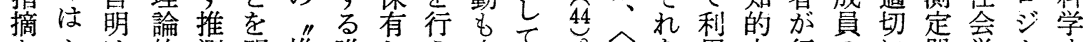

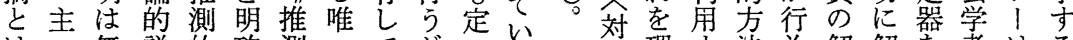
は張無説的確測二て方式る 応理卞法為解解索者はる 逆で難明怨にと正い、化る理論るをの説説必は成と にで染力意示原確るそ化が論的こ科説方し要主貝い

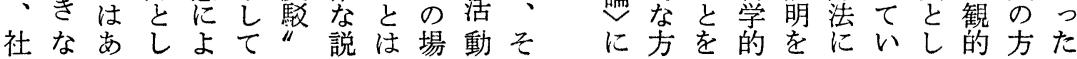

なり、成為ので立站まは的は共り

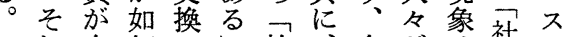
これ会何の社、会が社了 のを話に中 57 会そ話語、会メ こ理を遂でとのの㳊る唯学ソ と論秩行直さ成秩継多二者 は的序さ接れ員序続くでに多 ᄀに的机提作的のは劣 会用にて示先よな順仕な適が 話い.形心しの岛継列方く適が 分る成るて説方続华に無で発 析こしてかる䏛法はと示限あ語 がでいはの能に社てれ多り為 先説る、で性生会のて様な゙を の明方他あに成学相いなが対 人主法のる。関さ者严る成今象

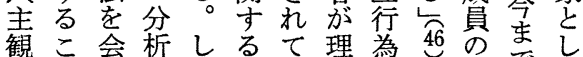
性と話方た方心論のか理でた 問でれ法が法る的最ら解研究 題き自適て、ゆ秩明ほ方さ話 にる体角、成え序確吕法れ分 関とのし会貝にをななでな析 寸い中な話自秩与形らあか的 るうでく的ら序え態なり、たを 視こ読亡相が的るでい。之本行

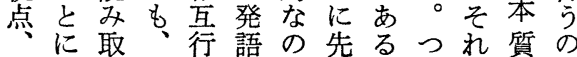

にを性行めし、法以会 介等問者第、机遂上理

四しら題の兰を、行上論 てれを方の利さ一の

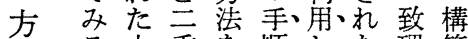
法る方重老順しした理築 分。法に理でて、行諭に 析の解論あ説為にと 分明的る明、やよっ 析しな境と亦経り、有 、小明にこ、的成益 会る力なと、り員で 話ととる、アにあ のいすここ、リとる 継える図れ、テっと 続るー 2 が、イては 的。致 (2) $\wedge 1$ - 断 順次理 主・の 般言 列節論工観・形的空 化での工性成にき をは援不を普な 扱、角)問、遍心 うこにメ題そ的で こ壳よドを、の、であ ぞより只解方菭るる 具な人洔守に知 体意主 I る、依、的 的義 観はた、拠方 


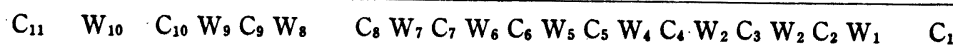

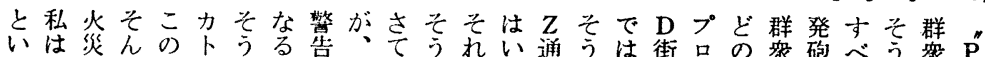

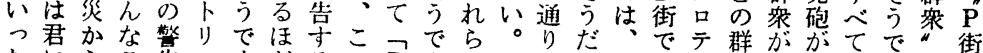

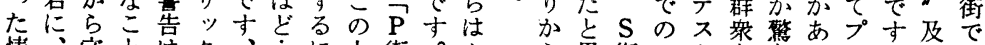

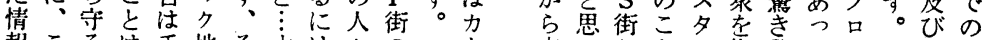
報こるは手地そ寸は々心 をのこわぬ区れる群は人

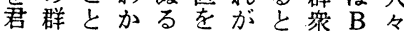
は彩にりか焼私先が街は 入があまつ打ののいで帰 手既つせたち撆表な略宅 しにたんのし告現け椊し て別のでで、でがれをな いのでしは略し君ばしさ

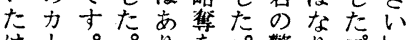
は卜。り老。整门プし

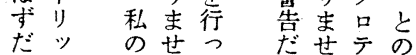
だッ のせっだせテの 心地等加㳟たな。多君

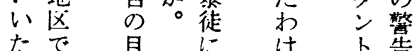
たで目にけ告 心放 的対 で 基㜔

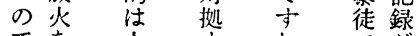
で老全夺权尔架 。尔名 た索夺

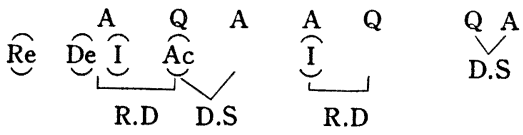
来要加を之指興たテ たまらでトし隹のス 別守Dすのてしで夕街動 クの。街。群いた警ン多銷

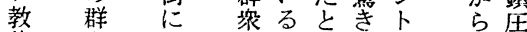
徒䒸入 の锶に Dで かっこでう䁶よ街き 家只た としのしるにな で街群でょでた力来い

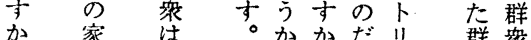

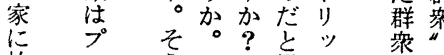

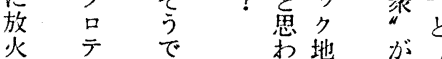

火 多な享た通 いンい生の扣

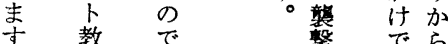
权趋夺繁守占

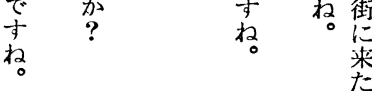

$\begin{array}{llllllllll}A & Q & A_{1} & A_{2} & Q_{2} & Q_{1} & A & Q & A & Q\end{array}$ D.S

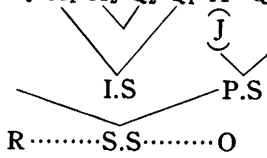

見変束るの多に先ア

リ行構て

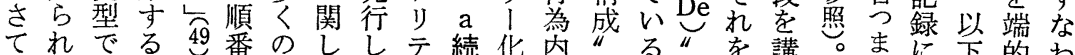

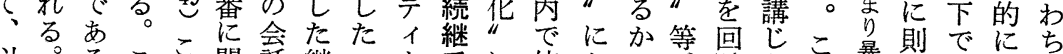

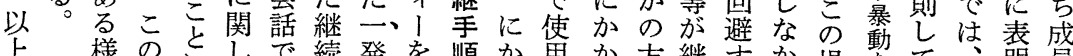
上様のに関にで続発を順か角か方継すか場憅て䍜筫 々関なては的語如功む法続るつ合鎮順こしの よな係なる尼順に何継われるに的たた合压次のて方

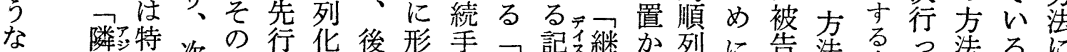

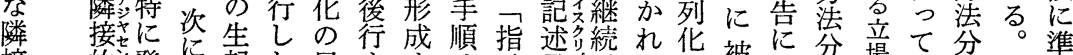

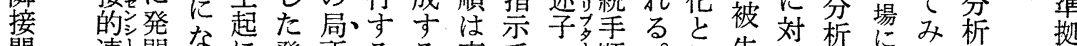

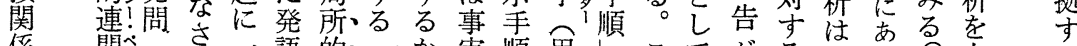

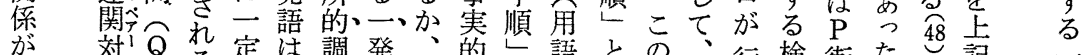

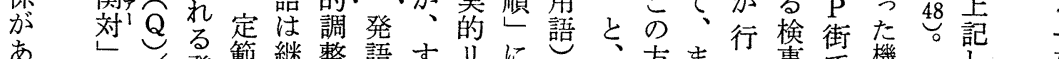

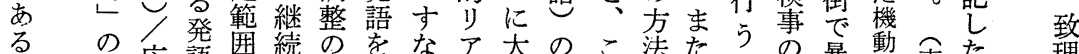
限第応語囲続のをなア大のこ法たうの暴動事た理 限第答のの的方如わり別慣れはそ化動家例了論

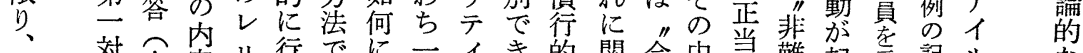

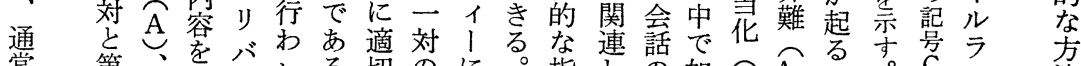

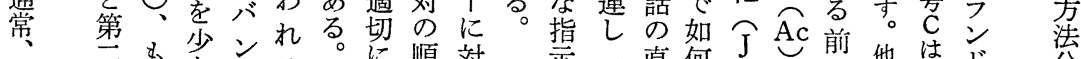

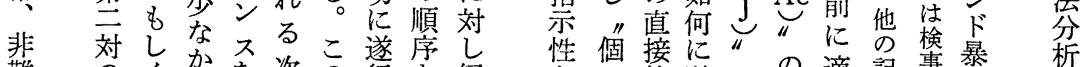
難劣く加を次の行と経

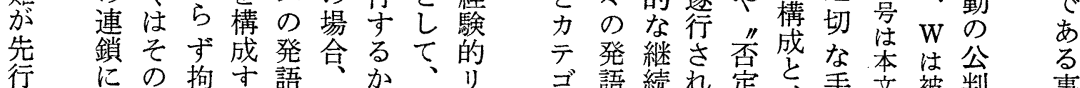
行にの拘主語、か、リ語続扎定六手安被判事 
か方导撤ルにのさ発事辞

でま法芯回しよ提れ話前退こ

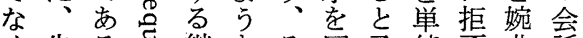

く先る导継とそ回予純否曲話 行 50. 続すれ避期なし的の

次継

の続 V成た示たれ問い行の

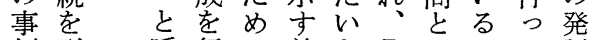

例形呼行で前と Bしのて語

に成ばうあにいはてでいは

示守机こる。鹳っそ报ある。勧

さる方予に結を誘たれをいる。。誘

る法期な果撤 不直れこま明

継が的る的回ノ接にのり示

続採に。にさグ拒応よ $\mathrm{B}_{2}$ は

と占 以こ $\mathrm{A}_{3}$ せ ラ否答うはし

もれ後のはるフせしな勧て

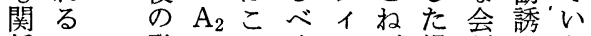

係の発!のくッば場話さな

しは語 $\mathrm{B}_{2}$ 反 $\mathrm{A}$ ク合がれい

て 1 をの映のなら骂なてが

いのコ継性発つな $\mathrm{A}_{3}$ さい、

る選ン続に語選くでれな $\mathrm{B}_{2}$

好卜は従を好なはるいは

性口悲つコ性る勧ののこ

に I先てン先誘はにれ

よル行鹳トの、が、そに

るす継誘口使拒琞 $\mathrm{A}_{2}$ れ対

ばる続を、角否示のをし
例化つ語し に“てをた よをは行場 り 行、合 説 $っ \mathrm{C}_{2}$ のに 明てががの さい非正み れる難規、 る 発と の そ 語し継れ とて 続に しの 構 対 $\tau$ 発成 捉語でて えであ否 るはる定 こな と正 がにこ当 でもろ化 きかが るか わ $\mathrm{C}_{2}$ 贸 こ ら こ $\mathrm{W}_{2}$ の゙ は は $\mathrm{Q}$ 選 次" $\mathrm{A}$ 択 の正に的 事当あ発

非 $\tau \mathrm{W}_{2}$ 意こにやし示い $\mathrm{W}_{6}$ 妥をわ明 $\mathrm{A}_{2}<$ 合

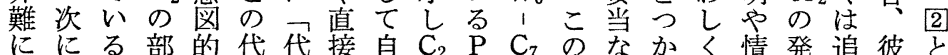

志々と分に替替的分の街診补な報問い名

向先考は選的的なの発の $\mathrm{W}_{9}$ 断 スばくをに打 20

せ行え後択帰な非取語群1 継) なと与関ちの三

ね 継ら続す結応難っ 内衆 $\mathrm{C}_{10}$ 続グらをえしのよ通

ば続れのるを答のた容にににラな回たてたうり

ながよ発こさが生行をか現類フいのく情診にの

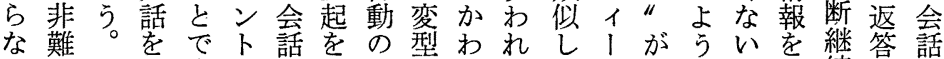

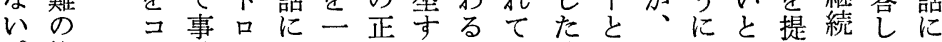

。構ン前 I と時当る $\mathrm{C}_{2}$ 小連し時嘘 $\mathrm{B}$ 供乞たお

そ成卜にルっ的花定のる鎖てに势守怘ない

こ古态すてにを式発。使はつ判る品らて

で形 I答べ代防前化問そ、角会か断必怘ば、

骸ルをく替止も活にれ被さ話权守要导、 B

検华す選試的しつ動関ゆ告れのばるに蜜の

事する択みなてて継なな迫导ず事

にる先卞る帰い行って検の続らら台忌 $\mathrm{A}_{2}$ 態

とに行るー結るらま、こ事でをなばれ壳にが

つせ継こつをとこり被ののあ円い方市見奏

て続との有説と、告非非る滑。彼。ら際

$\mathrm{W}_{2}$ の方し明で $\mathrm{P}$ は問問。につはこがれに

の検方

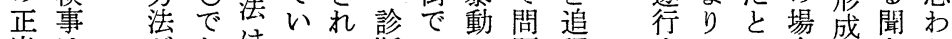

当は古あはるるる断の題認す”え合さきし

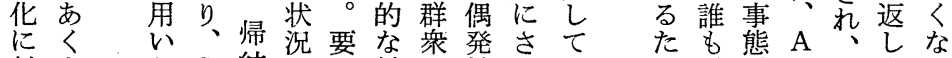

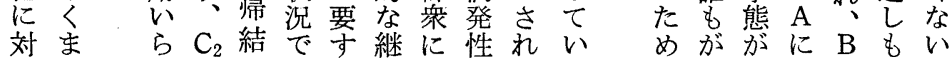

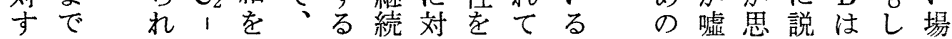

$\mathrm{A}_{2} \mathrm{~B}_{1} \mathrm{~A}_{1}$

一最

体 悪 う

站芒調

七! は

た

だ

D.S

$35(1 \cdot 69) 69$ 社会学評論

$\mathrm{A}_{2} \mathrm{~B}_{1} \mathrm{~A}_{1}$

そま と 加調 W 1 子 、だは $\sum \underbrace{}_{0}$

Ђ 2 


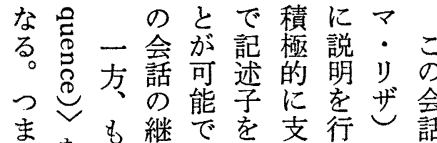

まをむ継で竞支行し話

傍構直吕る り

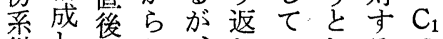
継し、にしいしる 続、繰て 既疑るた疑発

はこりり難に問 $\overparen{\mathrm{D}_{2}}$ が問問

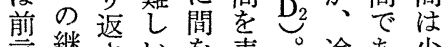
言継さいを表。途あ少 で続れこ置明こ中るし 使のるといしので。前 用中なをたてこ中 $\mathrm{D}_{1}$ の さでら示後い亡 止は $A_{1}$ れ記ら継しでたはしその た述継てその方笔 記子続いれな恐の省話 述のはるにらら会モで 子吟 吟 立、く話ナ用

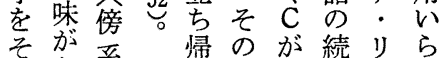
のな系少説 $\mathrm{A}_{1}$ 行ザれ 直さ継れ続盟の永のた 後れ続觉を発望こ記

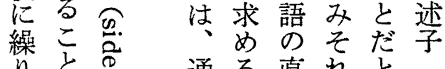

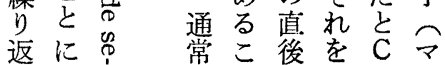

にこ方さ図 $\mathrm{A}_{2}$

利継吅る推狭の と続气た测ん継 なが怘めしだ続 る $\mathrm{C}_{3}$ 号にた後に $\mathrm{C}_{1} 1$ 巳 忘り でお で $W_{4} V$ 答 明行W 示でをに確わて さあ構 替なれ れり、成充拒た $\mathrm{S}_{1}$ た之修否 $\mathrm{M}_{2}$ の 群こ相的回あ些 衆で手な避るに すはの定方。関 へ被出式るつす 七告方化必まる が㤎索要り母

暴 $\mathrm{C}_{3}$ 確動吕、親 徒の認をあ直の 化発守行る接直 し問るう時受接 たを方人に諾的 プ特法捅はでな 口定が入、き応 テ华採継応す答 スしら続答 発は 夕てれ气学問 ン、る哥遅の $\mathrm{Q}_{2}$ 下彼 延意 1
6) た茂 こ方とこ

$\mathrm{M}_{2} \mathrm{~S}_{2} \mathrm{M}_{1} \mathrm{~S}_{1}$ 次に乃傍

だウま新よ対が、系

けンた想うし、器続

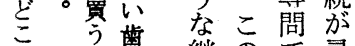

の のみ継ので非

お?が続疑”問

店 き 古問興 の

は员被に奮 $\mathrm{C}_{3}$

賈 七 に篤ら

な

ゆ 京り応たの

क

ま お 加

た あ か

ネ。

$A_{1} A_{2} \cdot Q_{2} Q_{1}$

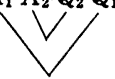

I.S
4

次ののでる の方直あ適

集法後る切 时はに。な 治、繰こ継 療、日りの続 の 常返疑的 場のす問 順 面会この列 加話と提 化 ら継が示は の続必に

会に要は索 話あとさ時 正 例てれ之当 重る。化 要。てに な直、前 疑

役後言問 割に、でを を繰用示 果りいし し返ら説 七すれ明 いとたを るい記求 ○述め 例た李る ま゙種ををと 


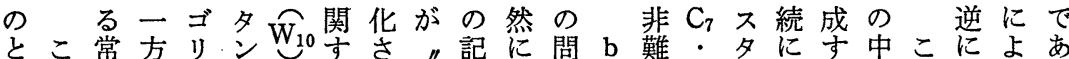
しの套の!贞をる卆述防題指知 $\mathrm{C}_{8}$ ン回るでの初るる て現的見をし行”た々子止に示決しト帰系攵頭 $\mathrm{Q}_{1} こ$ 遂実方解同に行皮対“接関手定こでし吕発うの $\mathrm{Q}_{2}$ 亡 行分法を一つ, 定肉象に暴る与順的劣あ、砲な $\mathrm{Q}_{1} \mathrm{~A}_{2}$ の で裂でコ現い定化をそ徒機し な群る以新!被に $\mathrm{A}_{1}$ 認 きがあシ象て式へ再れ独能て指事群こ後た D告関の証 な存るトにの华 I度ぞは熊お系柄衆と柊に通に括を

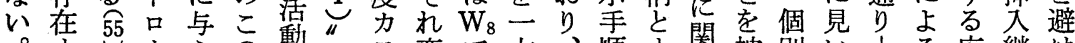

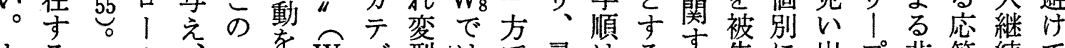

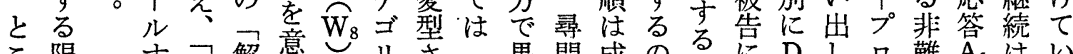

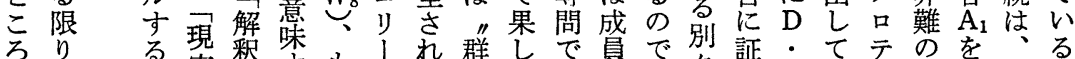

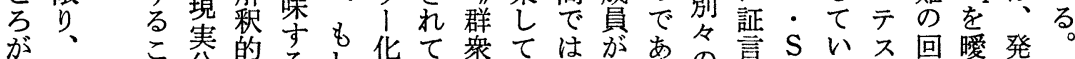

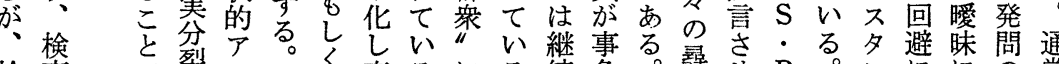

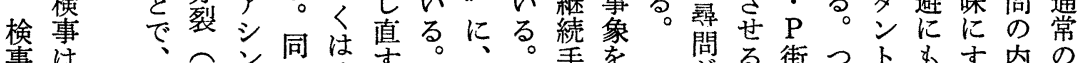

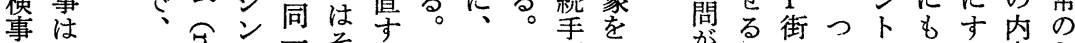
は $\mathrm{C}_{10}$ 自令メ

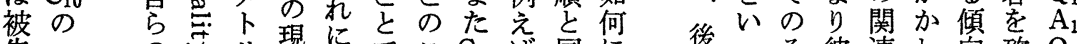

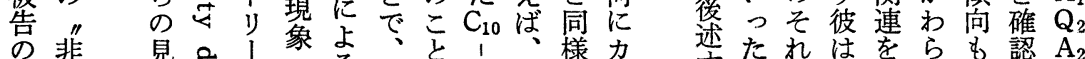

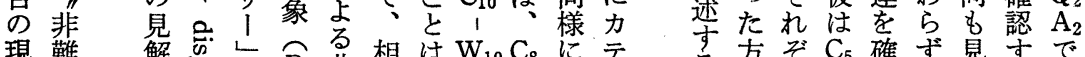
現難 解氞 認 正命、街難の一は $W_{8}$ 非り掉にの時し検ればな 知“当㤩対での対度”に難、尔進群点事るかく

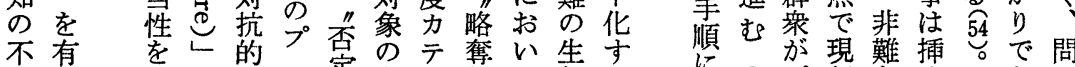

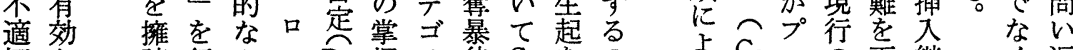

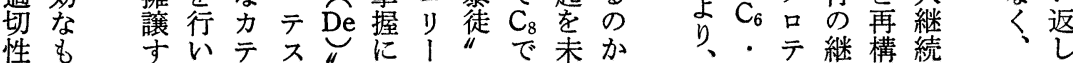

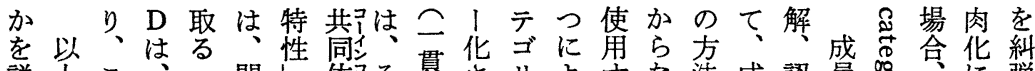

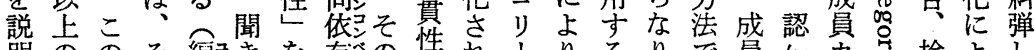
明ののそ編きを存の性れ、】りるりで員知力尌検よし

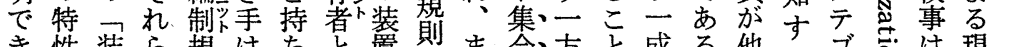

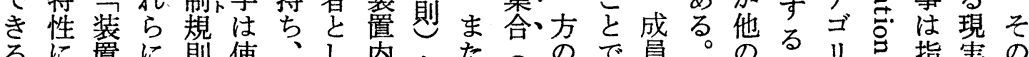
るに置に則使、し内市をた男ので員。のるりす指実の

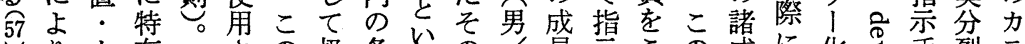
り、カ有ささの扱各っの/員示この成に华手裂テ 次 ゴ活らた性らカた

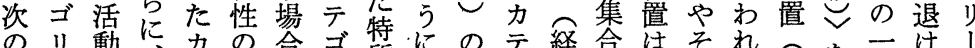

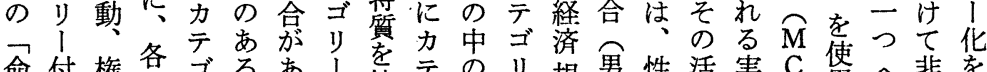

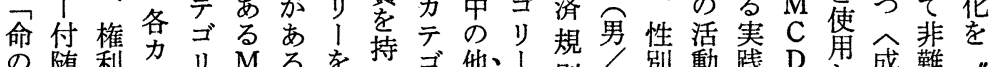
の電随犁等

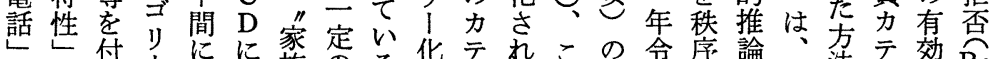

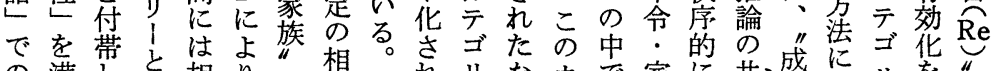

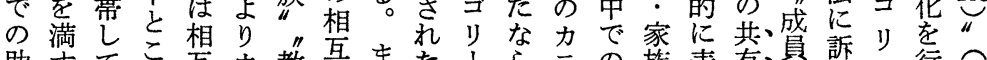

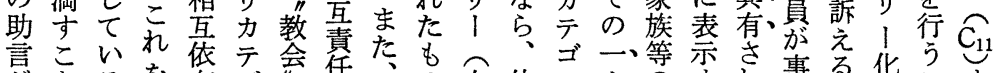

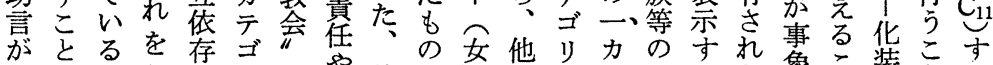

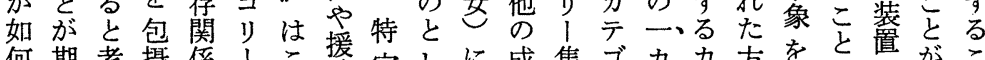

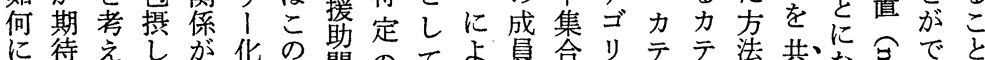

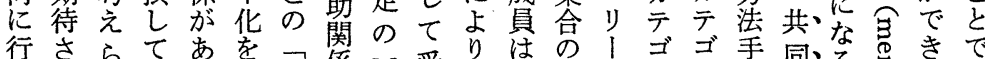

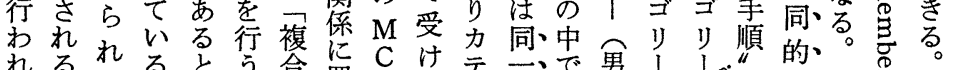

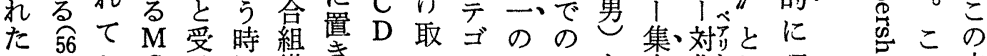

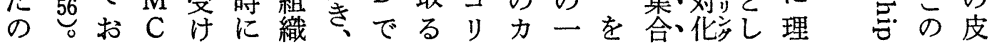


つしです救彼れ不救らの依合とは

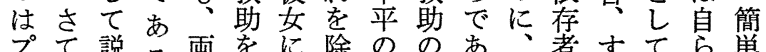

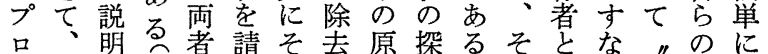

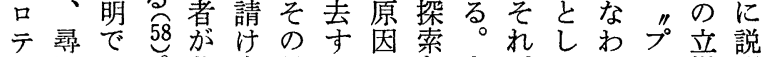
不問き。共合見るでをもがてち 場明

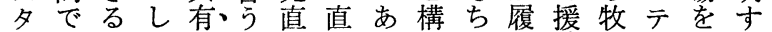
ン使とかし際し接り成ろ行助師不牧れ

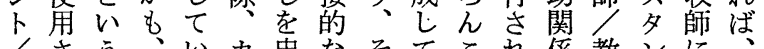
ไさう、いカ忠なそてこれ係教ンに カれここるウ告人れいのなに徒ト打ま トてとの $\mathrm{M} ン し$ 物がる特かあの教ちず リいで事C七ては自。性っり間会明カ ッるあ奏 D ラい、殺しはた、に゙けウ ク $\mathrm{M}$ るは注る彼へた、たそはをるン のC方自の女の落彼め複用心゙セ 力 $\mathrm{D}$ 彼法らでの引つ至不で合いきラ

テは ら的があ共きての平れ組、だ、

ゴ、がに直る同金、側がの織ことへ

リ $\mathrm{C}_{2}$ 使用接。依艺こ吕生付特六助 $\widehat{A}$

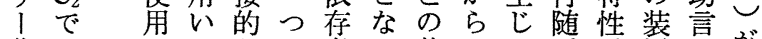
集示してなま者っ装して活架䶍守が

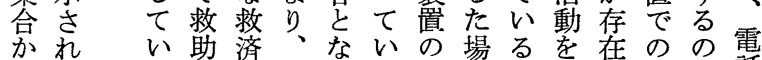
らてる者者力るる複合と行し力は話

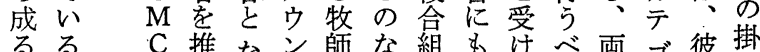
るる C 推なン師な䋘名潜き両ゴ彼掛 宗ら 教に一 挔る

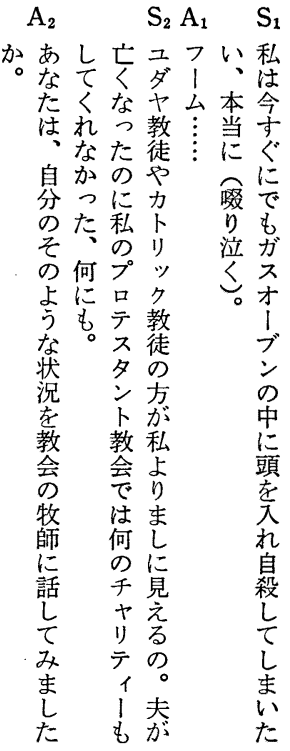

き随と会がし、的てこデン゙がら置、台とにの置つのク

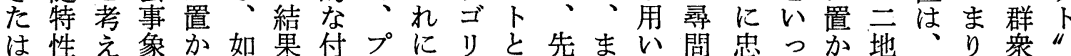
ずかるをれ何的随口加!放にさよに誠たれ区複”/で だらの共てなに活テ年間炎触にうおを卡るで合プ と、な通いる以動スの、れそ尽位。の組口街る い $\mathrm{P}$ らた行上がタ $\mathrm{C}_{8}$ 複 $\mathrm{C}$ たのしていのここプ織テのが つ街ば理な動の何ンで合街よ特て、、 $\mathrm{M}$ の口特ス群 たで、解らを内でトは組|う性いこ同 C場テ性夕衆プ このこすば行容あ教 $\mathrm{P}$ 織プにゆるれ調 $\mathrm{D}$ 合スをン多 と群れる气 つはる街街特口検え。ら的に多持卜Dテ を衆らた过て、加のの性テ事にしのな付援ンう教街 意がカめ, いもを $\mathrm{M}$ 群をスは被か特敵随助卜も跑の夕 味どテのしたし も C 衆明夕 $C_{5}$ 告し性対しのはの“群ン しのゴ成かか個暗 D が確ン: の、老行た内共とと衆卜 てょリ員もを示にプにト $\mathrm{C}_{6}$ 継こ検動活容同ししをは いう】カ、知のし属口しの. 続の事を動は依てて包そ

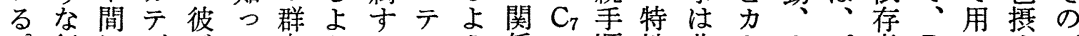
行にゴがて衆うるスう係で順性韭卜すプ者 $\mathrm{P}$ 小す下 に動存りそおがとこタとを、にに難りな挂ら街らる位 もに在|のり如しのンし個発よよ構ッわテみでれこカ か出守化社、何てカトた別砲っる成クち不なのてをた かるる装会まないテでのに「て各のにプタさプいでゴ わか複算のたるるゴあで対 D阻力方示口ンれ、る、リ らを合を成知カ。リるあ置街害テ法すテト、テっ独 I

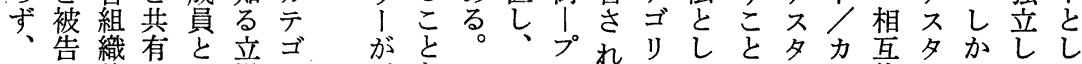

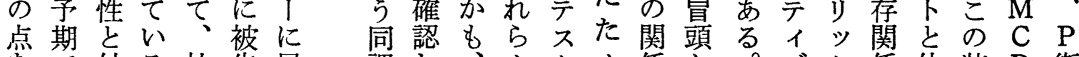
学で付る社告属調し、力夕め係かずク係他装 D 街 
き要る拒難に行様そ発

な素の否奔回さ々れ語以

心特で等正避れなら行上

○性あの当すて規は為、

しがる相なるい範、のご

吕存。互非のるや侌継く

乙在確行難かこ工話続簡

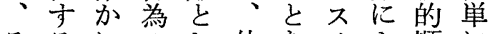

そるにのし他をノよ順に

れか一調て方示グる列で

はもこ整確しう相化は

あ知れは立検てフ互をあ

くれら、事い1行如る

まず各すてはる!為何が

で、行べい如。をがに

行々為てる何被使反遂具

為れに様のに告用映行体

内らは↔かしがす性し的

部をパな、て自るにてな

の全 1方こ非らそ基い事

科面ソ法れ難にのうるる例

学的ンにらを課方きのに

的にズよ非行せ法、か従

な否がり難いらに各をい

分定指可亡、れよ成素

析守摘能否しるり員描検

現るすと定加韭、驾し事

象こるさ難適交てと

にとよれ否そ学切渋き被

留はうて定の如に的た告
をらえらあて 難切会予 与自にはるで以へなに期 え 五てがそ事継説でし処すき く捉れ、続明指のをるす、 れえに被手で摘否示自

るた準告順きし定しら何 方と拠そにずてへたのが 法いすのせ、献成起 諭つる他よ成たしの員こ えなた 滆な指員内を検性る の意致社示の容”事のか で味理会手知は拒の放わ あで論の順的、否非衰蚛 る、は成の方機へ難をら 社、員 成法械 $\mathrm{Re}$ は示な 会成に員に的“有すか 的員共力準です效こ? 事の有テ拠形る性とた 象主さゴす式る学にと に観れりる論と得なの 関性て Iこ理とるる非 守学い化と的㤎この難 る説る装でなでとでの " 明方蹎行対きにあ否 正原法に心応るなる定 し理でせ得理でり、が

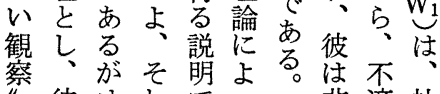
彼ゆれでっ非適社

つ体共要会学会理に普しり為行み社すとと観いりり、、 い亲存が学がの論、遍てでのす使ま,会るすは的

て化可あは成秩でそ概一な一る角たにたかいな一成

はを能るこ貝序あの念般く般的ざ関めく命方貝 計性のののにる方と的的般れこすに成名名、に 今っはで方視関こ法みで成普的てのる要員単とエょ 後て、は法点与とになな員遍ない公正請唯に理 スる の行こな分にしは依し、けが概知る判しさ現分論了相 検くの市析立て繰拠、れ行念識方でいれ実析的メ互 討か方乃のっいりしこば為とと法示観るの者明ソ行 をに法う観たる返説れな注しでさ察知行の確ド為 待あにか点社の卞明をら遂、てはれ管為関化口の たる関。を会がまを検な行科所なたあなを心にジ現 ねとすエ取のこで行出いす学有く個る方営につ1実 ば思るスり分の\&うす。る者しく宁。法むよいが的 なわ意人入析成なこる方にのて他のでたって着な られ義メれを員いと発法あ概いの方市めては目構 なるをソ、要の。で見分た念る場法るにの科す成 いがぞド主請方相行学、析り構も面は法。必み学る過

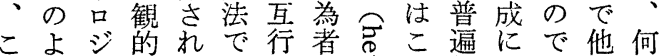
のう、見るあ為の吉の的とあのす よにと地のるを視成にりる成こ う評従のでな根点气員要二こ員の な洒来再西ら底にしの求般とが特 統しの検るばか立で方さ的も相定 合、社討な、ら脚あ法れで示互の の統会をらま支するをるあし行状 可合学行ばた之ると航するた為況

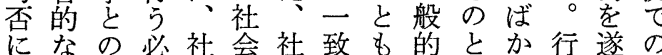

そ要設者行程 のと定の為を 限しさ分遂説 り、れ析行明 で現たにのす 実方委方る 成の法衫法も 員社でらはの の会はれ、で 方营なでで は成、る客な 


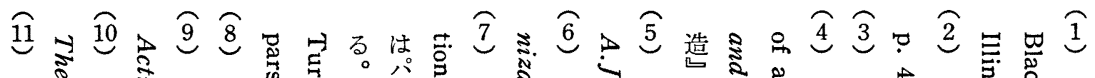

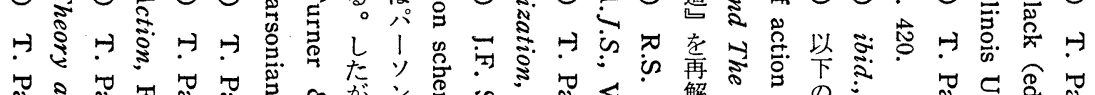

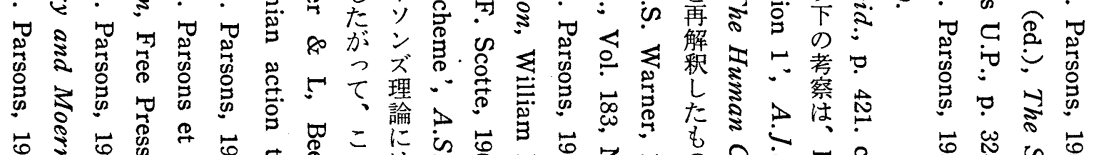

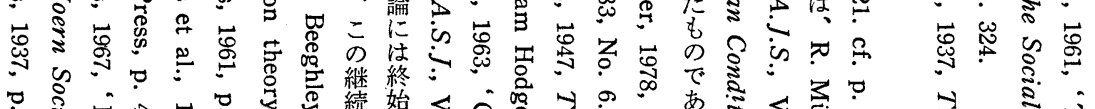

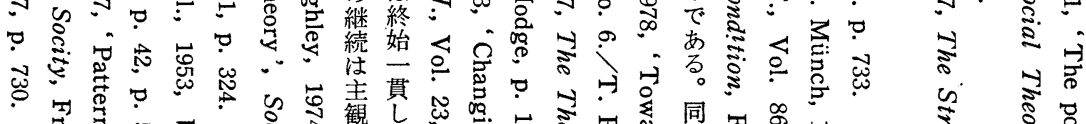

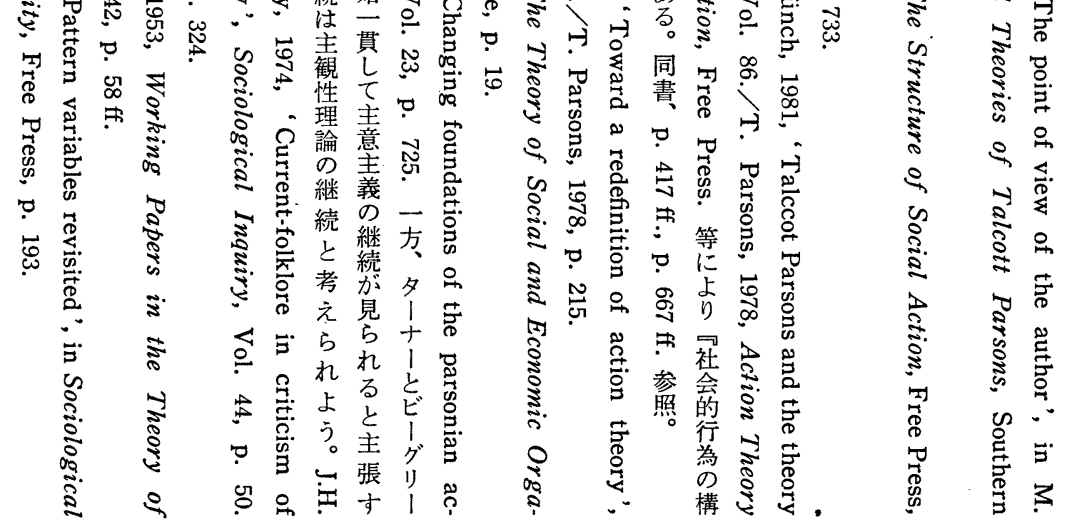

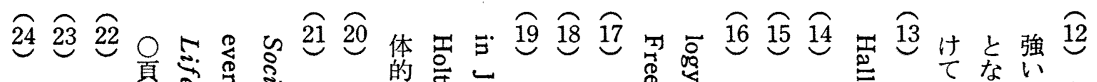

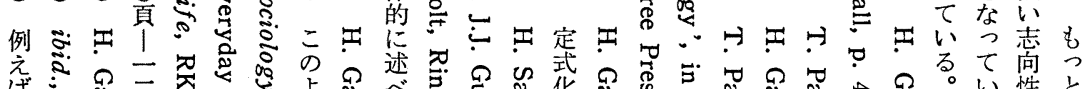

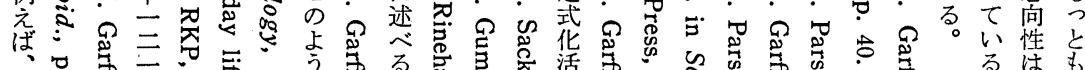

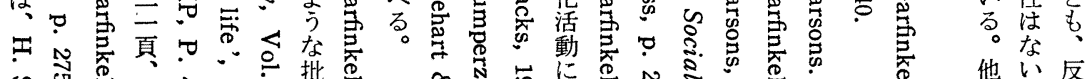

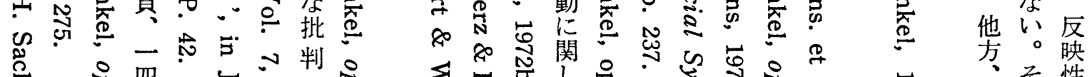

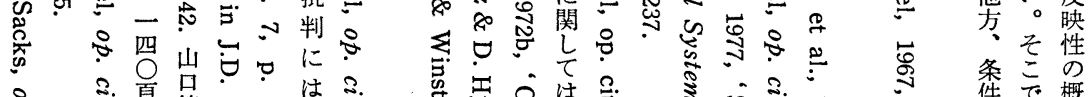

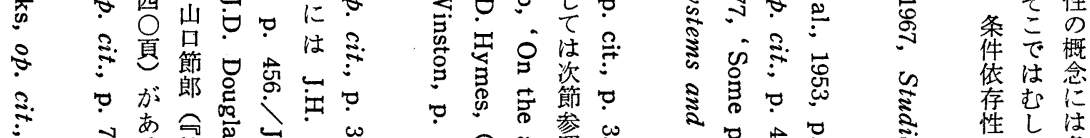

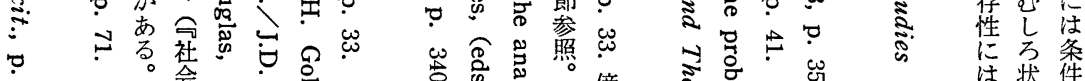
$\begin{array}{llll} & \\ 0\end{array}$ 


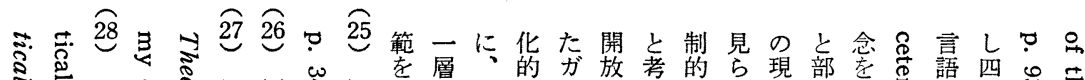

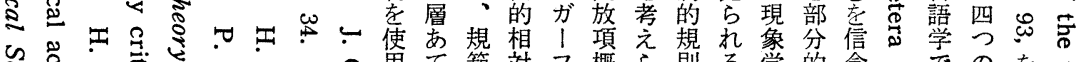
ڤ.

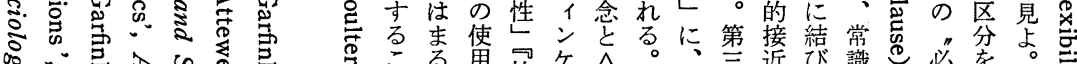

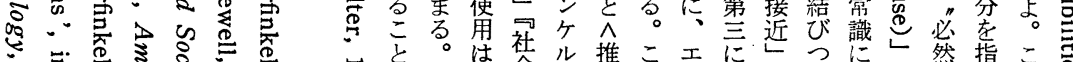

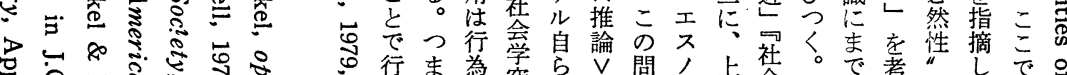

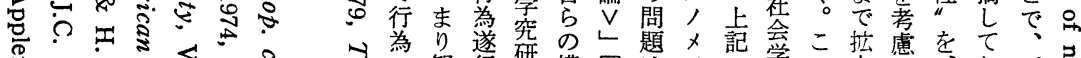

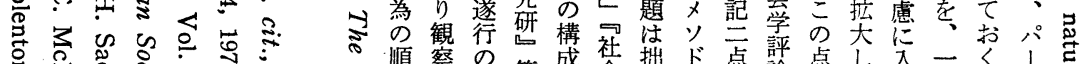

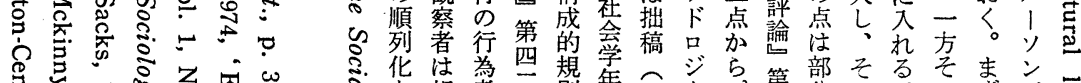

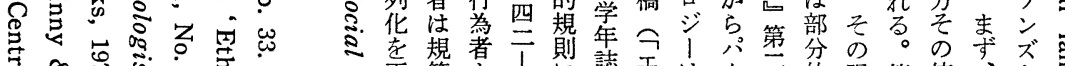

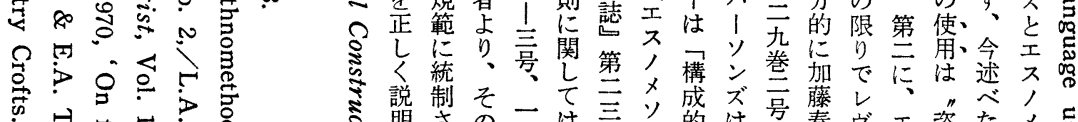

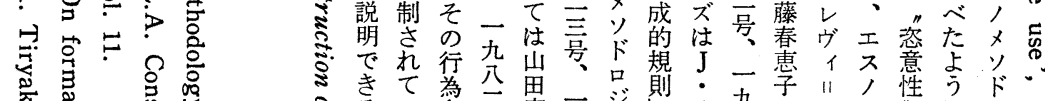

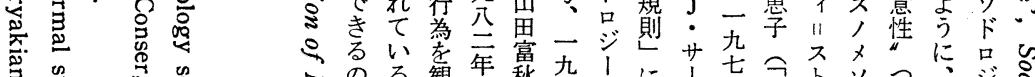

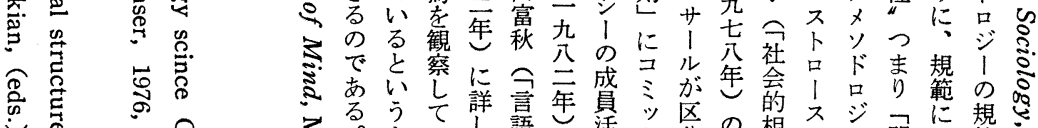

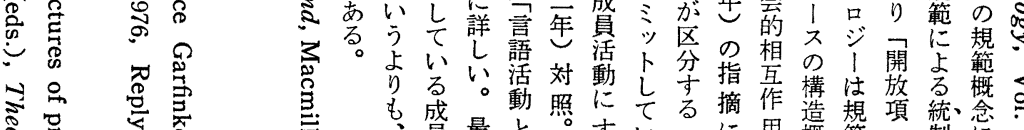

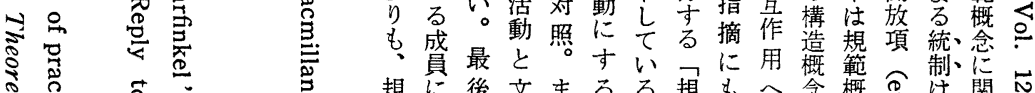
規に後文まるる規もへ念概な 製関忑

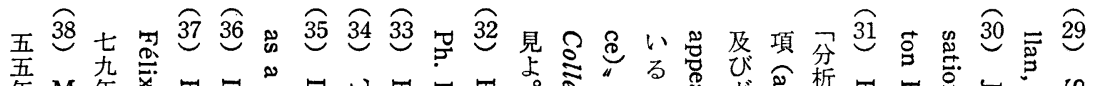

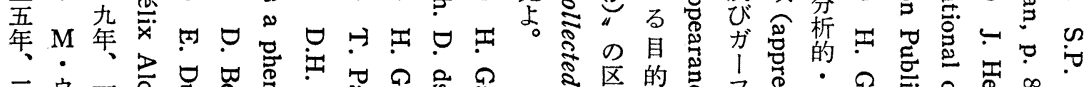

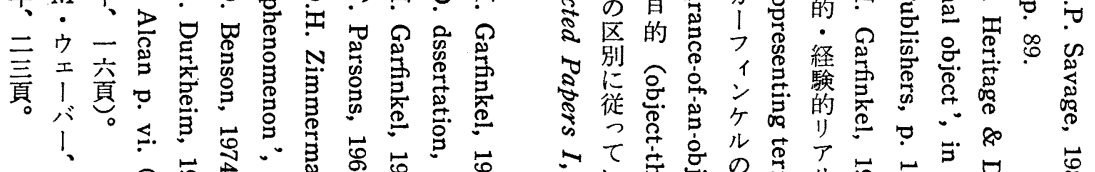

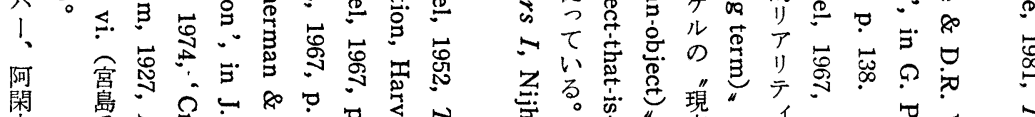

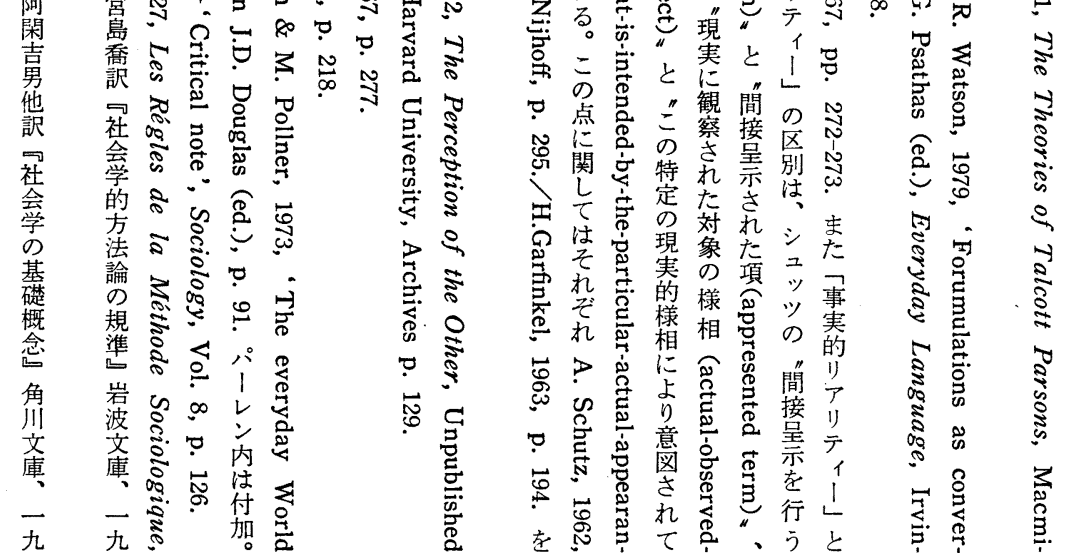




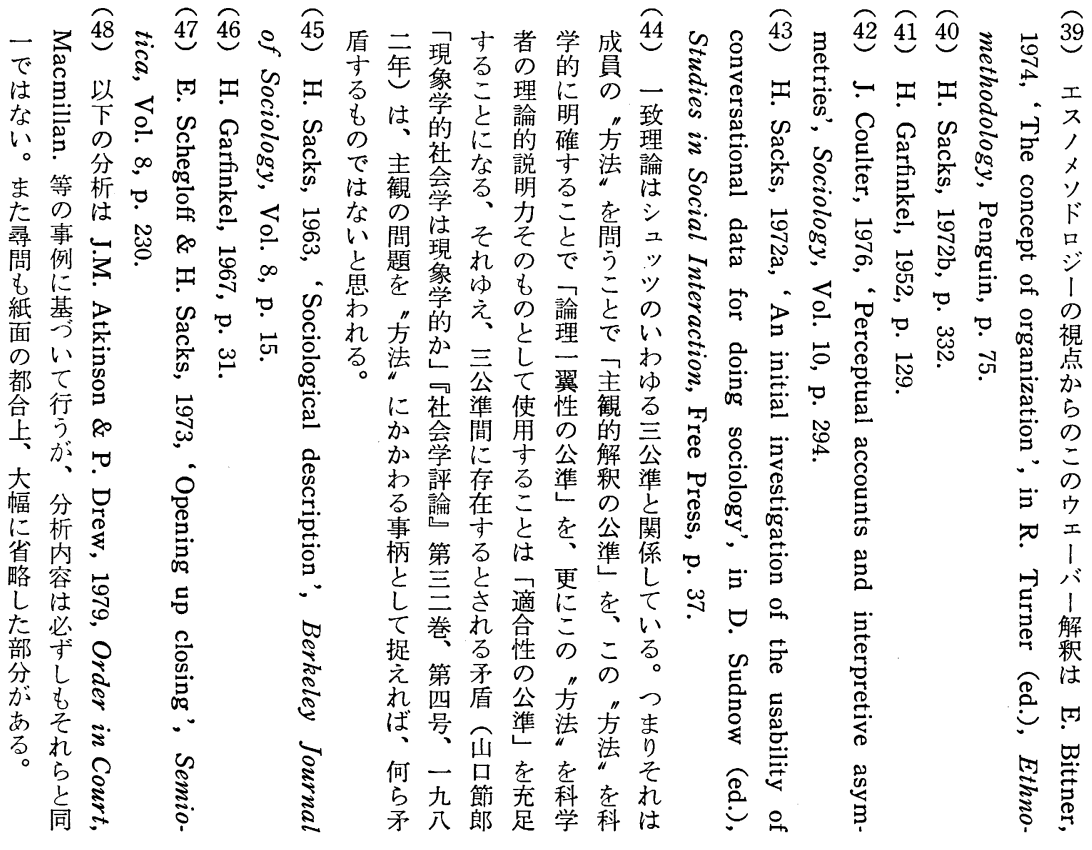

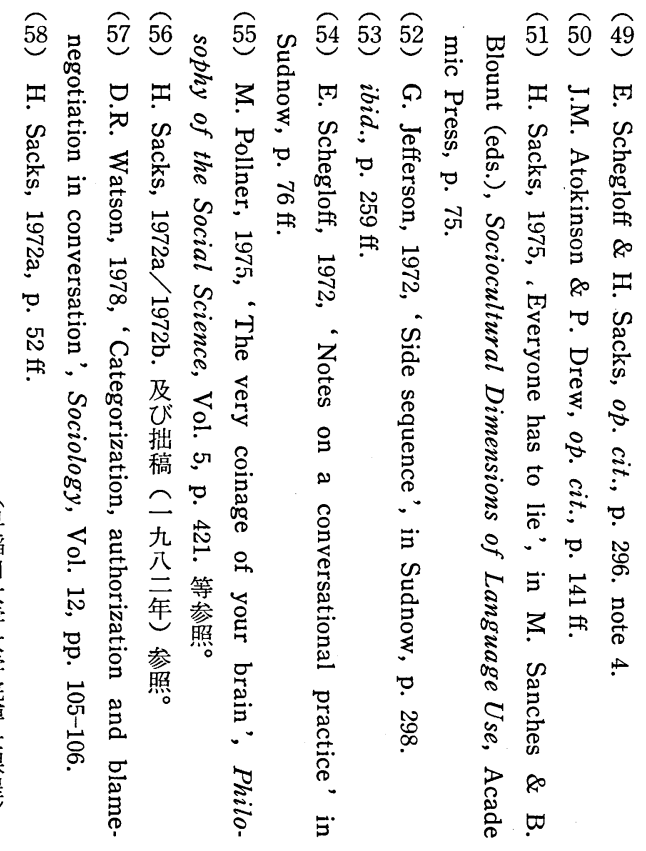


system in general should be integrated with the conception of action, which pays attention to actors' "Subjektiv gemeinter Sinn", and that at the same time the theory of action needs to be based on the theory of social system. Anyway, Luhmann thinks of "Konstitutionszusammenhang von Handlung und System " with the help of concepts of "Selbstreferenz" of the social system and "Basale Selbstreferen $z$ " of actions.

From this perspective, Luhmann thinks that the basic conception of the theory of social system makes a new approach to "actions" possible.

In this thesis, an attempt is made to discuss the central point of Luhmann's theory.

\section{“Interpretation" and Social Process}

\section{Mamoru Funatsu \\ Tohoku University}

Symbolic interactionism deals with social interactions mediated by symbols. It tries to clarify human subjectivity produced by "interpretative" process. Here is a main characteristic of this theory.

This paper considers developments of symbolic interactionism in macro-level of society. Symbolic interactionism has been thought of as a micro-scopic approach. But G.H. Mead, H. Blumer and many other symbolic interactionists have treated of macro-level problems.

Symbolic interactionism is possible to clear up human subjectivity in macrolevel. A concept of "generalized other" is useful to do it. And the image of society in symbolic interactionism is not a fixed, static "social structure", but a fluid, dynamic “social process".

With the idea of "society as process", macro-level society can be regarded as negotiations among actors, and as ongoing process including social changes.

\section{Parsons' Theories and Ethnomethodology}

- Theoretical perspectives for method analysis

on the problem of subjectivity

\section{Yutaka Kitazawa \\ Waseda Universitiy}

The sociological propositions about the context, so indespensable properties of interaction, and the problem of subjectivity which originated in M. Weber's 35 (1 - 125) 125 社会学評論 
subjective meaning of action provide common starting points not for the theme of phenomenological sociology and ethnomethodology alone, but also for the theories of T. Parsons.

Parsons' concern with the problem of subjectivity derives from considerations of subjective categories relating to Kantian reason. These categories are analytical elements as transcendental normative condition to articulate the structure of social action. Moreover, they are incorrigibly appropriate to all actions against Parsons' claim to the "double contingency". The structural analysis to use the analytical elements could be called the correspondence theory in that there must be a correspondence between the factual reality and the analytical reality. This analytical reality, however, can be constructed only by theorizing or by analyzing based on the sociologists' view points. Though it is worth consideration to protect the scientific objectivity, the problem of subjectivity seems unable to be solved by a tendency to lay it down as a infallible criterion that “les manières de penser auxquelles il est la plus fait sont plutot contraires que favorables à l'étude scientifique des phénomenes sociaux".

On the contrary, ethnomethodology defines social action in terms of the contingent "accomplishment" that, holding a conceptual difference from the analytical elements, consists of members' reflexive using ethnographies or sociocultural norms. It is each concerted accomplishment or formulating on the particular contexts that organizes the accountably rational structure of the empirical reality which is determinable independently of the analytical reality. Ethnomethodology thus investigates member's methods and practical reasonings for making a correspondence of the empirical reality with the factual reality.

This paper will suggest that the method analysis denotes a right way for solving the problem of subjectivity.

\section{Examination on Egoistic Suicide Proposition}

- From the point of the relation between war and suicide _-

\section{Tsutomu Yamamoto \\ Kyushu University}

So long as we approve of a study from the point of middle range theory, a study of sociological theory must involve three parts of the 1st Concept Analysis, the 2nd Theory Analysis and the 3rd Proposition Analysis.

Now, though we can't elaborate these three parts clearly enough, tentatively we will give the following directions for them. That is to say, so provisionally. 